\title{
Evaluating extraction methods to study canine urine microbiota
}

\author{
Ryan Mrofchak ${ }^{1}$, Christopher Madden ${ }^{1}$, Morgan V. Evans ${ }^{1,2}$, Vanessa L. Hale $\oplus^{1 *}$ \\ 1 Department of Veterinary Preventive Medicine, Ohio State University College of Veterinary Medicine, \\ Columbus, Ohio, United States of America, 2 Division of Environmental Health Sciences, Ohio State \\ University College of Public Health, Columbus, Ohio, United States of America \\ * hale.502@osu.edu
}

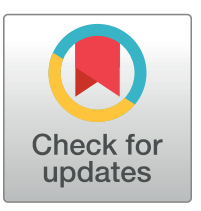

\section{G openaccess}

Citation: Mrofchak R, Madden C, Evans MV, Hale VL (2021) Evaluating extraction methods to study canine urine microbiota. PLOS ONE 16(7): e0253989. https://doi.org/10.1371/journal. pone.0253989

Editor: Peter Gyarmati, University of Illinois College of Medicine, UNITED STATES

Received: January 17, 2021

Accepted: June 16, 2021

Published: July 9, 2021

Peer Review History: PLOS recognizes the benefits of transparency in the peer review process; therefore, we enable the publication of all of the content of peer review and author responses alongside final, published articles. The editorial history of this article is available here: https://doi.org/10.1371/journal.pone.0253989

Copyright: ๑ 2021 Mrofchak et al. This is an open access article distributed under the terms of the Creative Commons Attribution License, which permits unrestricted use, distribution, and reproduction in any medium, provided the original author and source are credited.

Data Availability Statement: Sequencing data is available at NCBI Bioproject PRJNA689589.

Funding: Support for this project was provided by the Ohio State University College of Veterinary Medicine Canine Funds, the Infectious Disease

\section{Abstract}

The urinary microbiota is the collection of microbes present in urine that may play a role in host health. Studies of urine microbiota have traditionally relied upon culturing methods aimed at identifying pathogens. However, recent culture-free sequencing studies of the urine microbiota have determined that a diverse array of microbes is present in health and disease. To study these microbes and their potential role in diseases like bladder cancer or interstitial cystitis, consistent extraction and detection of bacterial DNA from urine is critical. However, urine is a low biomass substrate, requiring sensitive methods to capture DNA and making the risk of contamination high. To address this challenge, we collected urine samples from ten healthy dogs and extracted DNA from each sample using five different commercially available extraction methods. Extraction methods were compared based on total and bacterial DNA concentrations and bacterial community composition and diversity assessed through 16S rRNA gene sequencing. Significant differences in the urinary microbiota were observed by dog and sex but not extraction method. The Bacteremia Kit yielded the highest total DNA concentrations (Kruskal-Wallis, $p=0.165$, not significant) and the highest bacterial DNA concentrations (Kruskal-Wallis, $p=0.044$ ). Bacteremia also extracted bacterial DNA from the greatest number of samples. Taken together, these results suggest that the Bacteremia kit is an effective option for studying the urine microbiota. This work lays the foundation to study the urine microbiome in a wide range of urogenital diseases in dogs and other species.

\section{Introduction}

Urine, in the absence of urinary tract infection, has long been considered sterile; a principle still taught in many healthcare professional settings to date. However, evidence counter to this idea has been accumulating for several decades [1]. Culture-positive asymptomatic bacteriuria is commonly reported in women and older adults; although, this is sometimes deemed "contamination" based on bacterial counts $<10^{5}$ [2]. Culture-negative symptomatic urinary tract infections (UTIs) are also common, and can, in some cases, be attributed to fastidious organisms that fail to grow using standard urine culturing (SUC) techniques [2-8]. More recently, culture-independent next-generation sequencing of urine and enhanced quantitative urine 
Institute, and the Department of Veterinary Preventive Medicine (RM, CM, MVE, VLH). MVE was additionally supported by Ohio State University College of Public Health Collaborative Postdoctoral Research funding. The funders had no role in study design, data collection and analysis, decision to publish, or preparation of the manuscript.

Competing interests: The authors have declared that no competing interests exist. culture (EQUC) has revealed the presence of bacteria in $>90 \%$ of individuals-including those with and without UTIs and from urine collected via free-catch, transurethral catheter, or suprapubic aspirates [5-7, 9-14]. Collectively, this work provides evidence for the presence of a urinary microbiota containing live bacteria that are present in healthy individuals.

A growing body of work has revealed profound links between the microbiota (oral, gut, lung, vaginal) and host health [15-19]-from nutrient metabolism [20], to immune development and defense [21], and colonization resistance [22]. Thus, it follows that the urine / bladder microbiome may also have a critical role in host health, but it has been far less studied than the microbiota of the aforementioned body regions. Notably, the "urine is sterile" dogma contributed to the exclusion of urine in the first phase of Human Microbiome Project (HMP) launched in 2007 [23]. In 2014, the second phase of the HMP launched and included the urine / bladder microbiome. However, work on the urine microbiome continues to lag. Although urine is not sterile, it has a low microbial biomass, making it more challenging to characterize and at greater risk for contamination [24]. Despite this, several recent studies on urine have identified clear shifts in the microbial community associated with age [10, 25-30], sex [12, 31, 32], urgency urinary incontinence in women [10,33-35], bladder cancer [31, 36-42], interstitial cystitis [43-49], neuropathic bladders [50, 51] and pneumonia [52]. However, additional work is needed to identify definitive and mechanistic links between the urine / bladder microbiome, host health, and urinary tract disease.

Urinary tract disease is one of the most common diagnoses in veterinary medicine $[53,54]$. In addition, dogs are a valuable translational model for many human diseases, including urogenital diseases like bladder cancer [55]. However, there have only been two studies, to our knowledge, characterizing canine urine microbiota $[56,57]$ and none evaluating canine urine DNA extraction methods. Multiple methods of urine microbial DNA isolation have been reported in human studies $[12,51,58-61]$, and there are a few studies that have compared microbial DNA extraction methods. These studies include a comparison of methods for extracting fungal [62] and viral DNA from urine $[59,63,64]$ as well as a study on methods to reverse crystal precipitates that interfere with DNA extraction [65]. Yet, only one recent study has evaluated urine DNA extraction methods in relation to the bacterial microbiota in humans [61], and there are no comparable studies in dogs. In this study, our objective was to compare canine urine bacterial DNA quantity and $16 \mathrm{~S}$ rRNA sequencing results of five commonly used extraction methods. These extraction methods included four DNA isolation kits from Qiagen - Bacteremia, Blood and Tissue, PowerFecal ${ }^{\circledR}$, and PowerFecal ${ }^{\circledR}$ Pro-and an extraction protocol using magnetic beads.

\section{Materials and methods}

\section{Sample collection}

This study was approved by The Ohio State University College Institutional Animal Care and Use Committee (IACUC \#2019A00000005). Mid-stream free catch urine samples were collected from 10 healthy dogs in September 2019 at The Ohio State University College of Veterinary Medicine (Columbus, OH, USA) with owner consent. Enrollment criteria included: a body weight of at least $30 \mathrm{lbs}(\sim 13.6 \mathrm{~kg})$ and the ability to produce $>30 \mathrm{ml}$ of urine in a single urination. Dogs were excluded if they had any history of urinary tract disease or antibiotic use within three weeks of sample collection. We collected urine samples from a total of $10 \mathrm{dogs}$, including 4 males ( 3 neutered) and 6 females ( 5 spayed). The average age of the dogs was 3.7 years old (range: $0.75-10$ years) and represented multiple breeds including: one Great Pyrenees, one Labrador Retriever, one Golden Retriever, and seven mixed breed dogs. Full metadata on each dog is available in S1 Table. All urine samples were stored on ice immediately 
after collection and transported to the laboratory within 6 hours of urination. Samples were then transferred into a $-80^{\circ} \mathrm{C}$ freezer where they remained until extraction.

\section{DNA extraction}

Five extraction methods were tested: QIAamp ${ }^{\circledR}$ BiOstic $^{\circledR}$ Bacteremia DNA Kit (B), DNeasy ${ }^{\circledR}$ Blood and Tissue Kit (BTL), QIAamp ${ }^{\circledR}$ PowerFecal ${ }^{\mathbb{R}}$ DNA Kit (PF), QIAamp ${ }^{\circledR}$ PowerFecal ${ }^{\mathbb{R}}$ Pro DNA Kit (PFP) (Qiagen, Venlo, Netherlands) and an extraction protocol using magnetic beads (MB) [66]. Each protocol incorporated varying chemical, mechanical, and thermal lysing steps to facilitate DNA extraction (Table 1).

To prepare urine samples for extraction, $3.0 \mathrm{ml}$ of urine was centrifuged at $4^{\circ} \mathrm{C}$ and 20,000 $\mathrm{x} g$ for 30 minutes. Samples that underwent MB extraction were centrifuged at $4^{\circ} \mathrm{C}$ and 20,000 $\mathrm{x} g$ for 20 minutes. After centrifuging, the supernatant was removed and discarded and the pellet was used for extraction. Samples were assigned initials unique to each $\operatorname{dog}(\mathrm{AW}, \mathrm{CB}, \mathrm{CS}$, DD, DH, HB, LS, SF, SM, and ZR). Extraction methods were abbreviated as seen in Table 1 (B, BTL, MB, PF, or PFP). Negative and positive controls were also extracted from each method. The negative control was a blank (no sample) tube that underwent the full extraction process. The positive control was $3.0 \mathrm{ml}$ of urine from dog AW spiked with $3 \times 10^{8} \mathrm{CFUs}$ of Melissococcus plutonius. M. plutonius is a honeybee pathogen that would not be expected in the urine / gut of dogs [67]. Brief descriptions of each extraction method are included below.

Bacteremia (B). Urine pellets were resuspended in a lysis buffer (MBL) and placed in a $70^{\circ} \mathrm{C}$ water bath for 15 minutes. Samples then underwent two rounds of bead beating $(6 \mathrm{~m} / \mathrm{s}$ for 60 seconds with a 5 minute rest between rounds). Bead beating was performed on a MP FastPrep-24 ${ }^{\mathrm{TM}} 5 \mathrm{G}$ (MP Biomedicals, Santa Ana, California, USA). After bead beating, the samples were cleaned with an Inhibitor Removal Solution. The remainder of the protocol was followed with two modifications. First, centrifugation was performed at 13,000 $\mathrm{x} g$ instead of $10,000 \mathrm{x} g$. Second, during the final step, DNA was eluted into $50 \mu \mathrm{l}$ of elution buffer (EB) and incubated at room temperature for five minutes; then, the first eluate was run through the silica membrane of the spin column a second time to maximize DNA yield.

Blood and Tissue with Lysozyme (BTL). Urine pellets were resuspended in a lysis buffer adapted from Pearce et al., 2014. The lysis buffer consisted of 10mM tris, 1mM EDTA, 1.0\% SDS, pH 8.0, and $20 \mathrm{mg} / \mathrm{mL}$ lysozyme (Sigma Aldrich, St. Louis, MO) [10, 29, 68, 69]. The

Table 1. Mechanical, chemical and thermal lysis properties of each extraction method.

\begin{tabular}{|c|c|c|c|c|c|c|}
\hline Kit & $\begin{array}{l}\text { Mechanical } \\
\text { lysis? }\end{array}$ & $\begin{array}{l}\text { Mechanical lysis } \\
\text { method }\end{array}$ & $\begin{array}{l}\text { Chemical } \\
\text { lysis? }\end{array}$ & Chemical lysis method & $\begin{array}{c}\text { Thermal } \\
\text { lysis? }\end{array}$ & Thermal lysis method \\
\hline Bacteremia (B) & yes & bead beating & yes & Lysis buffer (MBL) & yes & $70^{\circ} \mathrm{C}$ heat block / water bath for $15 \mathrm{~min}$. \\
\hline $\begin{array}{l}\text { Blood and Tissue with } \\
\text { Lysozyme (BTL) }\end{array}$ & no & $\mathrm{N} / \mathrm{A}$ & yes & $\begin{array}{l}\text { Lysozyme }(10 \mathrm{mM} \text { EDTA, } \\
1.0 \% \mathrm{SDS}, 20 \mathrm{mg} / \mathrm{ml} \\
\text { lysozyme) }\end{array}$ & yes & $\begin{array}{l}37^{\circ} \mathrm{C} \text { heat block / water bath for } 1 \text { hour (with } \\
\text { lysozyme) }\end{array}$ \\
\hline Magnetic Beads (MB) & no & $\mathrm{N} / \mathrm{A}$ & yes & $\begin{array}{l}10 \mathrm{mM} \text { tris, } 2 \mathrm{mM} \text { EDTA, } \\
\text { and } 1 \% \mathrm{SDS}\end{array}$ & yes & $\begin{array}{l}65^{\circ} \mathrm{C} \text { water bath for } 30 \mathrm{~min} \text {. Three freeze / thaw } \\
\text { cycles-liquid nitrogen for } 1 \text { minute followed by } \\
65^{\circ} \mathrm{C} \text { for } 5 \text { minutes. }\end{array}$ \\
\hline PowerFecal $^{\circledR}(\mathrm{PF})$ & yes & bead beating & yes & $\begin{array}{l}\text { Lysis buffer (Powerbead } \\
\text { Solution) }\end{array}$ & yes $^{\mathrm{a}}$ & $\mathrm{N} / \mathrm{A}$ \\
\hline $\begin{array}{l}\text { PowerFecal }{ }^{\circledR} \text { Pro } \\
\text { (PFP) }\end{array}$ & yes & bead beating & yes & Lysis buffer (CD1) & no & N/A \\
\hline
\end{tabular}

Mechanical, chemical and thermal lysis properties of each extraction method.

${ }^{a}$ This manufacturer protocol includes a thermal lysing step; however, we used a modified version of this protocol, skipped the thermal lysing step, and performed two rounds mechanical lysing using a bead beater rather than the vortex adapter indicated in the protocol.

https://doi.org/10.1371/journal.pone.0253989.t001 
urine pellet and lysis buffer were then incubated in a $37^{\circ} \mathrm{C}$ water bath for 1 hour. The remainder of the extraction protocol was followed per manufacturer instructions with one modification. In the final step, DNA was eluted in $50 \mu$ of elution buffer (AE), incubated at room temperature for five minutes; then, the first eluate was run through the silica membrane of the spin column a second time.

Magnetic Beads (MB). Per Liu et al. (2017), urine pellets were resuspended in a lysis buffer composed of $10 \mathrm{mM}$ tris, $2 \mathrm{mM}$ EDTA, and $1 \%$ SDS, $\mathrm{pH}$ 8.0. The suspension was then frozen in liquid nitrogen for 1 minute followed by incubation in a $65^{\circ} \mathrm{C}$ water bath for $5 \mathrm{~min}$ utes; the freeze / thaw process was repeated three times. After the third freeze / thaw step, suspensions were incubated for 30 minutes in a $65^{\circ} \mathrm{C}$ water bath. Suspensions were then centrifuged at 20,000 $\mathrm{x} g$ for five minutes. After completing the lysis step and centrifugation, the supernatant was placed in PCR tube strips containing AMPure XP magnetic beads (Beckman Coulter, Indianapolis, IN). The supernatant and magnetic beads were homogenized and incubated at room temperature, then placed on a magnetic separator for 5 minutes. During this step, lysed DNA was drawn to magnetic beads in the tube strips. The remaining supernatant was removed and beads were washed with $80 \%$ ethanol. This was repeated twice. After washing, DNA-bound beads were dried in a $37^{\circ} \mathrm{C}$ heat block for 15 minutes [66]. Dried DNAbound beads were then resuspended in $40 \mu \mathrm{l}$ Qiagen ${ }^{\odot} \mathrm{C} 6$ solution. Resuspended samples were then placed on a magnetic separator for 1-2 minutes to pellet beads. The resulting supernatant contained DNA used in downstream analyses.

PowerFecal ${ }^{\circledR}(\mathbf{P F})$. Urine pellets were resuspended in lysis buffer (PowerBead Solution $+\mathrm{C} 1)$ and subjected to two rounds of bead beating $(6 \mathrm{~m} / \mathrm{s}$ for 60 seconds with a five-minute rest between cycles). Samples then underwent multiple inhibitor removal and purification steps. The remainder of the extraction protocol was followed with two modifications. During the second round of centrifuging, after applying the ethanol-based wash solution (C5) to the spin column, samples were centrifuged for 2 minutes (instead of 1 minute) to remove residual wash solution. In the final step, DNA was eluted in $50 \mu$ of elution buffer (C6), incubated at room temperature for five minutes; then, the first eluate was run through the silica membrane of the spin column a second time.

PowerFecal ${ }^{\mathbb{R}}$ Pro (PFP). Urine pellets were resuspended in lysis buffer (CD1) and subjected to two rounds of bead beating $(6 \mathrm{~m} / \mathrm{s}$ for 60 seconds with a five-minute rest between cycles). The remainder of the extraction protocol involving multiple inhibitor removal and purification steps was followed as written with one modification. In the final step, DNA was eluted in $50 \mu \mathrm{l}$ of elution buffer (C6), incubated at room temperature for five minutes; then, the eluent was run through the silica membrane of the spin column a second time.

DNA yields from all samples were then quantified on a Qubit ${ }^{\circledR} 4.0$ Fluorometer (Invitrogen, Thermo Fisher Scientific ${ }^{\mathrm{TM}}$, Carlsbad, CA, USA) using a 1X dsDNA High Sensitivity Assay. Hereafter, DNA concentrations measured using Qubit ${ }^{\mathbb{R}}$ are referred to as total DNA concentrations.

\section{Quantification of bacterial DNA by qPCR}

Bacterial DNA was amplified using $16 \mathrm{~S}$ rRNA bacterial primers and probes per Nadkarni et al. (2002) on a QuantStudio ${ }^{\mathrm{TM}} 3$ Real-Time PCR System (Applied Biosystems ${ }^{\mathrm{TM}}$, Thermo Fisher Scientific ${ }^{\mathrm{TM}}$, Carlsbad, CA, USA). $300 \mathrm{nM}$ of forward primer ( $5^{\prime}-$ TCCTACGGGAGGCAGC AGT- $\left.3^{\prime}\right), 300 \mathrm{nM}$ of reverse primer (5'-GGACTACCAGGGTATCTAATCCTGTT- $\left.3^{\prime}\right)$, and $175 \mathrm{nM}$ of probe ((6FAM)- $5^{\prime}$-CGTATTACCGCGGCTGCTGGCAC- $3^{\prime}$-(TAMRA)) were added to each reaction. qPCR cycling parameters were as follows: $50^{\circ} \mathrm{C}$ for $2 \mathrm{~min}, 95^{\circ} \mathrm{C}$ for 10 min (initial denaturation) and 40 cycles of $95^{\circ} \mathrm{C}$ for $15 \mathrm{~s}$ (denaturation) and $60^{\circ} \mathrm{C}$ for $1 \mathrm{~min}$ 
(annealing and extension) [70]. To be included in analysis, at least two replicates per sample had to amplify. Following qPCR, cycle thresholds were $\log _{10}$-transformed using the equation listed below under "qPCR standard curve," and the antilog of each sample was used to calculate the bacterial DNA concentration in each sample.

\section{qPCR standard curve}

DNA extracted from an Escherichia coli isolate was used to generate a standard curve for qPCR. Five ten-fold dilutions of $E$. coli DNA ranging from approximately $5 \times 10^{4} \mathrm{pg} / \mu \mathrm{l}$ to $5 \mathrm{x}$ $10^{-1} \mathrm{pg} / \mu \mathrm{l}$ were run in triplicate using the primers, probe, cycling parameters, and the QuantStudio instrument described above. DNA concentrations were then $\log _{10}$-transformed and plotted against cycle threshold values on a linear regression using R package ggplot2 v.3.3.2. The resulting equation was $y=-5.329 x+36.504\left(R^{2}=0.984\right)$ where $y$ is the cycle threshold and $\mathrm{x}$ is the $\log _{10}$-transformed DNA concentration. To calculate estimates of the absolute cell counts in each sample, Escherichia coli was used as a standard, and the bacterial DNA concentrations were divided by the theoretical weight of one E. coli cell (4.96 fg DNA) per Nadkarni et al. 2002. Estimates of the absolute cell counts were then multiplied by relative abundances of specific taxa (e.g. Sphingomonas and Pasteurellaceae bacterium canine oral taxon 272) to obtain and compare absolute cell counts of these taxa.

\section{S rRNA sequencing and sequence processing}

DNA underwent library preparation and sequencing at Argonne National Laboratory. Library preparation was performed as follows: the V4 region of the 16S rRNA gene was amplified using primers 515F and 806R [71, 72]. PCR reactions $(25 \mu \mathrm{L})$ contained $9.5 \mu \mathrm{L}$ of MO BIO PCR Water (Certified DNA-Free), $12.5 \mu \mathrm{L}$ of QuantaBio's AccuStart II PCR ToughMix ( $2 \mathrm{x}$ concentration, $1 \mathrm{x}$ final), $1 \mu \mathrm{L}$ Golay barcode tagged Forward Primer $(5 \mu \mathrm{M}$ concentration, $200 \mathrm{pM}$ final), $1 \mu \mathrm{L}$ Reverse Primer ( $5 \mu \mathrm{M}$ concentration, $200 \mathrm{pM}$ final), and $1 \mu \mathrm{L}$ of template DNA. The following PCR conditions were applied: $94^{\circ} \mathrm{C}$ for 3 minutes to denature the DNA, with 35 cycles at $94^{\circ} \mathrm{C}$ for $45 \mathrm{~s}, 50^{\circ} \mathrm{C}$ for $60 \mathrm{~s}$, and $72^{\circ} \mathrm{C}$ for $90 \mathrm{~s}$; with a final extension of $10 \mathrm{~min}$ at $72^{\circ} \mathrm{C}$. Amplicons were then quantified using PicoGreen (Invitrogen) and a plate reader (Infinite ( 200 PRO, Tecan). Equimolar volumes of the amplicons were pooled into a single tube. This pool was then cleaned using AMPure XP Beads (Beckman Coulter), and quantified with a fluorometer (Qubit, Invitrogen). After quantification, the molarity of the pool was diluted to $2 \mathrm{nM}$, denatured, and then diluted to a final concentration of $6.75 \mathrm{pM}$ with a $10 \% \mathrm{PhiX}$ spike. Amplicons were sequenced on an Illumina MiSeq (Lemont, IL, USA) using V2 chemistry with $2 \times 250$ bp paired-end reads and customized sequencing primers and procedures [71]. Sequencing data is available at NCBI Bioproject PRJNA689589.

Raw, paired-end sequence reads were processed using QIIME2 v. 2020.2 [73]. The DADA2 plugin was used to truncate reads at $230 \mathrm{bp}$ and trim $33 \mathrm{bp}$ from the left side of both forward and reverse reads [74]. These parameters were used to ensure primers and barcodes were removed and to denoise paired end reads. Taxonomy was assigned on the resulting amplicon sequence variants (ASVs) in QIIME2 using the Silva 132 99\% database from the 515F / 806R classifier $[75,76]$. We opted not to rarefy at 300 reads as this drastically decreased diversity and eliminated rare taxa. Rarefaction can also increase Type 1 errors and variance where overdispersion can mask differential abundance between samples [77]. To avoid these issues and account for rare taxa, an unrarefied table was used as input in $\alpha$ - and $\beta$-diversity metrics. 


\section{Statistical analyses}

Total DNA concentrations (as measured by Qubit) and bacterial DNA concentrations (as calculated from qPCR) were tested for normality using the Shapiro Wilk Normality Test in R version 3.5.2. DNA concentrations and 16S rRNA read numbers were analyzed using the Kruskal-Wallis Rank Sum Test. Statistical significance was achieved if the p-value was less than 0.05 .

Prior to 16S rRNA sequencing analysis, singletons (ASVs with only one read in the entire dataset) were excluded. We then used the R package decontam and applied both the frequency and prevalence (at a 0.5 threshold) methods to identify and remove putative contaminants from our dataset (R package, v.1.10.0) [78]. All diversity metrics were computed using the R package phyloseq with a p-value cutoff of 0.05 adjusted using the Benjamini \& Hochberg False Discovery Rates [79]. To analyze bacterial diversity, three $\alpha$-diversity metrics were used: Observed Features (equivalent to richness), Shannon, and Simpson. Kruskal-Wallis Rank Sum Tests were used to compare $\alpha$-diversity results to categorical variables of interest (extraction method, sex, dog). Post-hoc pairwise comparisons were calculated using Pairwise Wilcoxon Rank Sum Tests. To compare bacterial composition between groups (extraction method, sex, $\operatorname{dog}$ ), three $\beta$-diversity metrics were used: Bray Curtis, Unweighted UniFrac, and Weighted UniFrac. A permutational analysis of variance (PERMANOVA) based on Euclidean distance matrices and 1000 permutations was used to quantify these differences (adonis 2 function, $R$ package vegan v.2.5.6). Multilevel pairwise comparisons for dog and extraction method were calculated using pairwise PERMANOVAs with 1000 permutations [80]. An Analysis of Composition in Microbiomes (ANCOM) in QIIME2 was used to identify differentially abundant taxa between groups (extraction method, sex, dog).

\section{Results}

\section{Urine total DNA concentrations}

We extracted DNA from a total of 10 dogs using 5 different methods. A single positive and negative control were also extracted using each kit. Total DNA concentrations were measured on a Qubit fluorometer (S2 Table) and were not normally distributed (Shapiro-Wilk Normality Test, $p=<0.0001$ ). Twenty-six samples (by kit $=9$ PFP, $6 \mathrm{MB}, 4 \mathrm{~B}, 4 \mathrm{PF}, 3 \mathrm{BTL}$; by dog $=4$ AW, 1 AWS, 1 CB, 4 CS, 5 DD, 3 DH, 4 HB, $1 \mathrm{LS}, 1$ SF, and 2 SM) and all 5 negative controls (one per method) had concentrations that were too low to read $(<0.01 \mathrm{ng} / \mu \mathrm{l})$. Quantifiable DNA concentrations ranged from $0.02 \mathrm{ng} / \mu \mathrm{l}$ to $1.37 \mathrm{ng} / \mu \mathrm{l}$ for all other samples including positive controls. The number of samples with quantifiable DNA varied by extraction method (Fig 1A). BTL extracted quantifiable DNA from nine urine samples (including the positive control). B and PF extracted DNA from eight urine samples (including the positive controls). MB and PFP extracted DNA from six and two samples, respectively (Fig 1A). Notably, no DNA was recovered from the spiked positive control sample using PFP. Total DNA concentrations did not differ significantly by method (Fig 1B, Kruskal-Wallis, $p=0.165$ ), but did differ significantly by sex (Fig 1C, Kruskal-Wallis, $p=0.0007$ ) and by dog (Fig 1D, Kruskal-Wallis, $p=0.001$ ). Males had significantly higher DNA concentrations; however, no pairwise comparisons of DNA concentrations were significant by dog (S3 Table). B produced the highest average total DNA concentrations, followed by PF, BTL, MB, and PFP.

\section{Urine bacterial DNA concentrations}

Bacterial DNA concentrations were measured in triplicate via qPCR (S2 Table) and were not normally distributed (Shapiro-Wilk Normality Test, $p=<0.0001$ ). Twenty-two samples (by 
$\mathbf{a}$
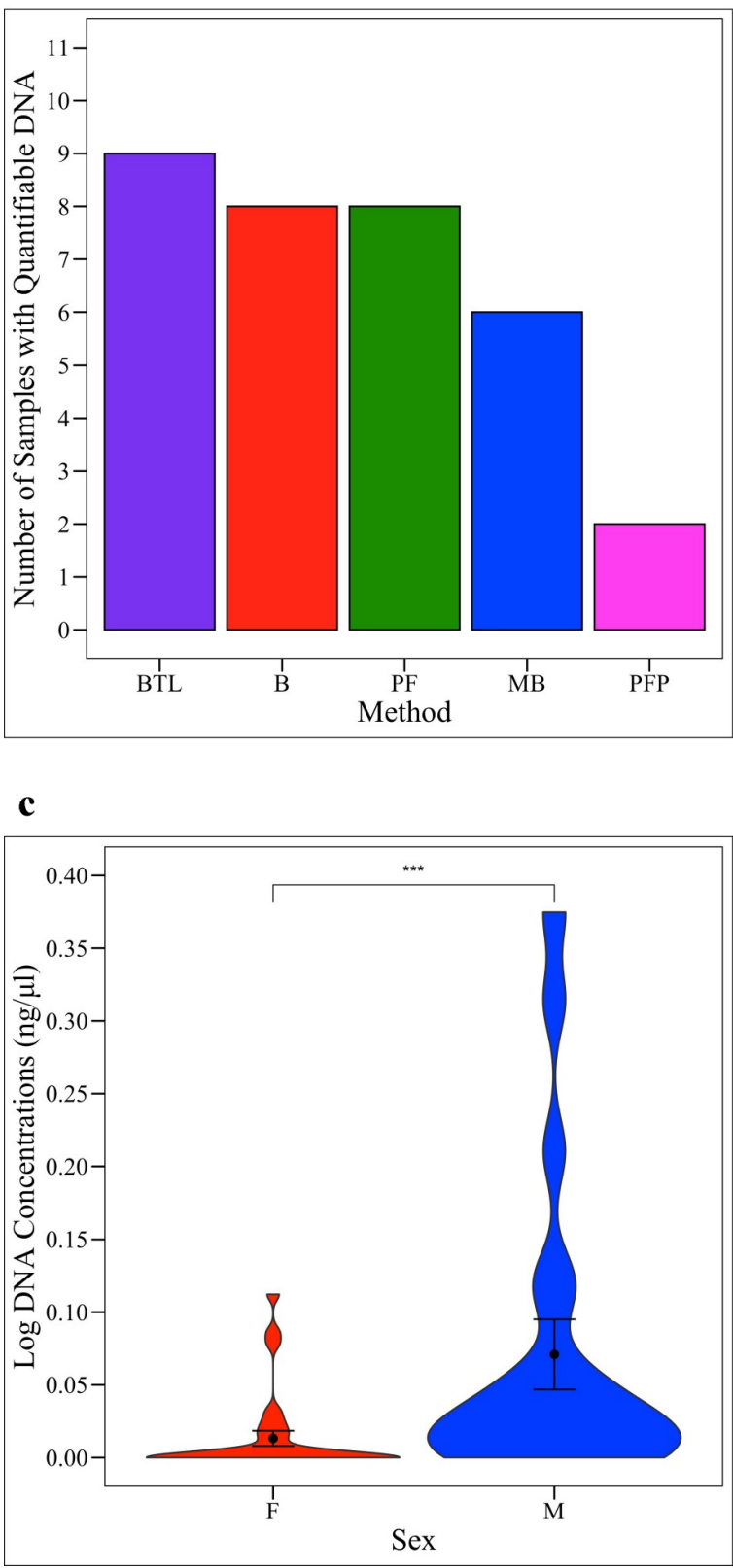

b

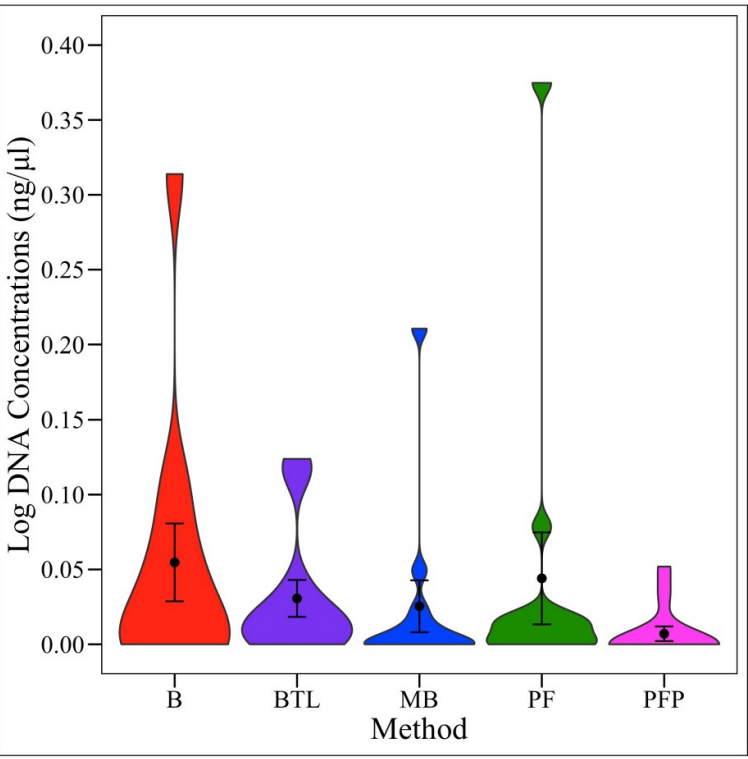

d

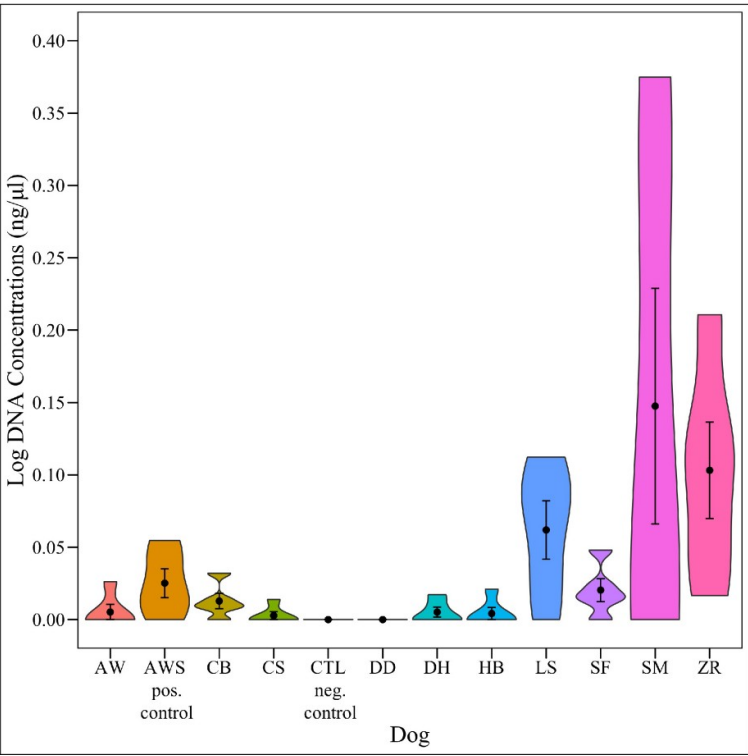

Fig 1. Total DNA concentrations. (a) Number of samples with measurable total DNA by extraction method (negative control excluded). Total DNA concentration, measured via Qubit, by (b) extraction method, (c) sex, and (d) dog. Total DNA concentrations did not differ significantly by extraction method (Kruskal-Wallis, $p=0.165$ ) but did differ significantly by sex (Kruskal-Wallis, $p=0.0007$; males $>$ females), and dog (Kruskal-Wallis, $p=0.001$ ). By dog, no pairwise comparisons were statistically significant. $\mathrm{B}=\mathrm{Bacteremia}$, $\mathrm{BTL}=$ Blood \& Tissue with Lysozyme, $\mathrm{MB}=$ Magnetic Beads, $\mathrm{PF}=$ PowerFecal ${ }^{\mathbb{R}}, \mathrm{PFP}=$ PowerFecal ${ }^{\mathbb{R}}$ Pro, $\mathrm{F}=\mathrm{Female}, \mathrm{M}=\mathrm{Male}$.

https://doi.org/10.1371/journal.pone.0253989.g001

kit $=5 \mathrm{MB}, 8 \mathrm{BTL}, 5 \mathrm{PFP}, 3 \mathrm{PF}, 1 \mathrm{~B}$; by dog = 2 AW, 1 AWS, $5 \mathrm{CB}, 1 \mathrm{CS}, 2 \mathrm{DD}, 4 \mathrm{DH}, 4 \mathrm{HB}, 2$ $\mathrm{SF}$, and $1 \mathrm{SM}$ ) and all 5 negative controls did not amplify any bacterial DNA. In total, twentyseven samples did not amplify bacterial DNA. Five samples (4 MB and 1 PFP) were excluded for failing to have at least two replicates amplify (S2 Table). All samples exhibited less than 3\% variation in cycle threshold values between replicates with three exceptions: the spiked positive control extracted using MB (5.6\% variation), and samples from dogs SF (6.1\% variation) and 
$\mathbf{a}$

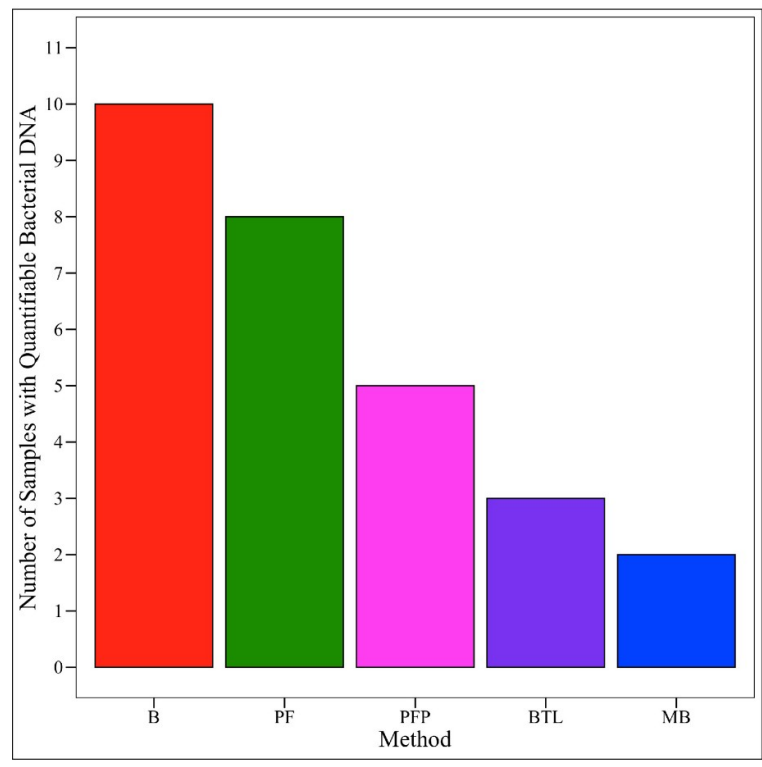

c

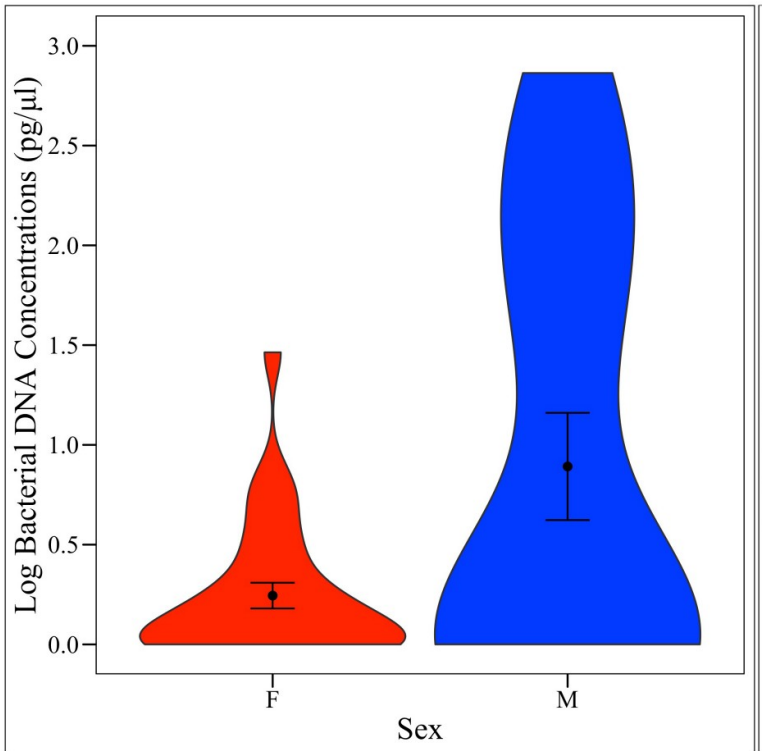

b

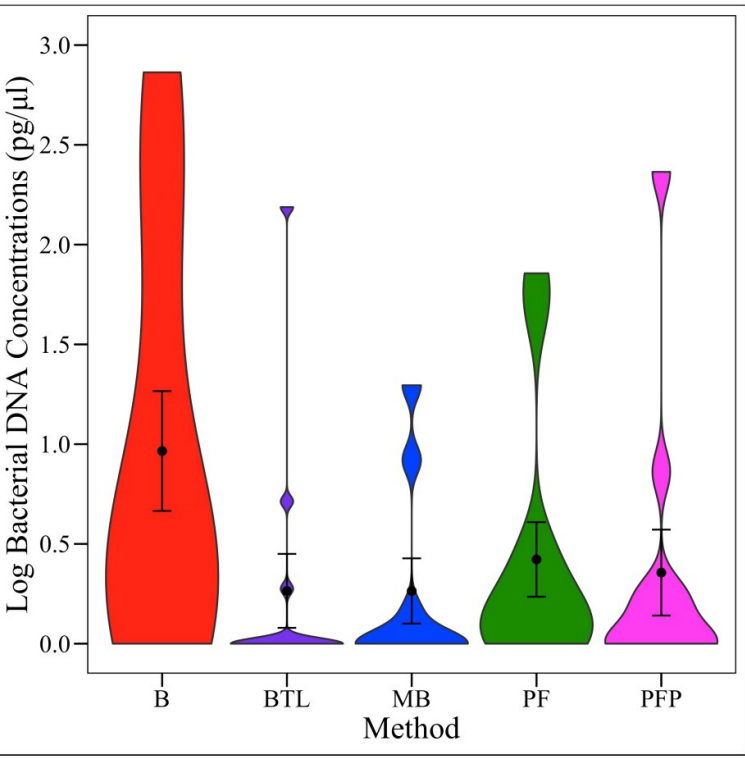

d

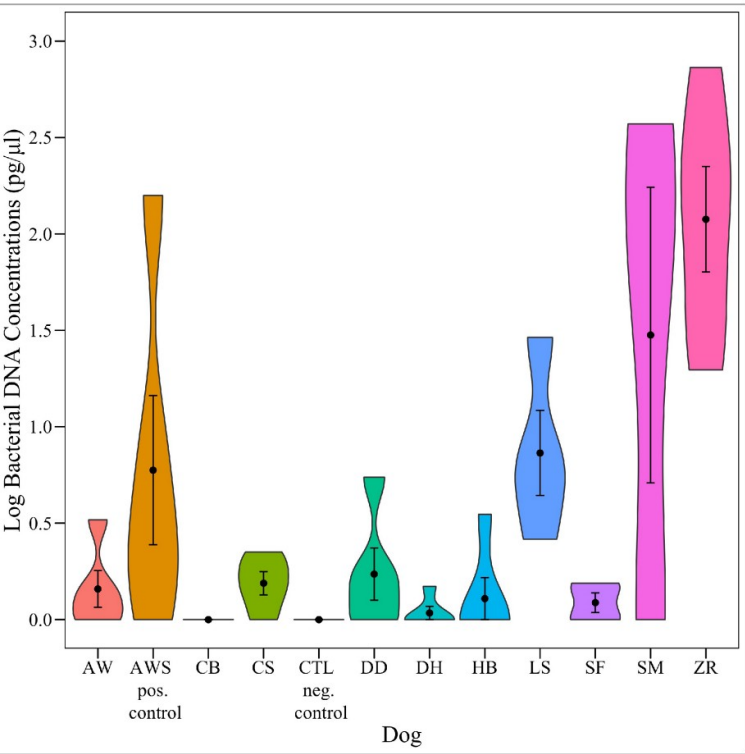

Fig 2. Bacterial DNA concentrations. (a) Number of samples with measurable bacterial DNA by extraction method. Bacterial DNA concentrations, calculated via qPCR, by (b) extraction method, (c) sex and (d) dog. Bacterial DNA concentrations differed significantly by extraction method (Kruskal-Wallis, $p=0.044$ ) and by $\operatorname{dog}$ (Kruskal-Wallis, $p=0.0005$ ); although, no pairwise comparisons were significant. Bacterial DNA concentrations did not differ significantly by sex (Kruskal-Wallis, $p=0.333$; positive control excluded).

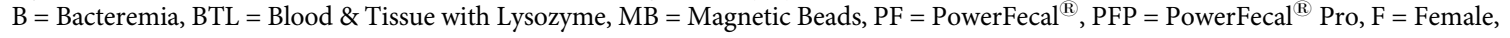
$\mathrm{M}=$ Male.

https://doi.org/10.1371/journal.pone.0253989.g002

SM (3.4\% variation) extracted using the B kit. All three samples were included in analyses. Quantifiable bacterial DNA concentrations ranged from $0.28 \mathrm{pg} / \mu \mathrm{l}$ to $729.48 \mathrm{pg} / \mu \mathrm{l}$. The number of samples with quantifiable bacterial DNA varied by extraction method (Fig 2A). Additionally, bacterial DNA concentrations differed significantly by method (Fig 2B, KruskalWallis, $p=0.044$ ) and by $\operatorname{dog}$ (Fig 2D, Kruskal-Wallis, $p=0.0005$ ); although, no pairwise 
comparisons by method or dog were significant ( $\mathrm{S} 4 \mathrm{Table}$ ). B yielded the highest bacterial DNA concentrations and extracted quantifiable bacterial DNA from the greatest number of urine samples (Fig 2A). Bacterial concentrations did not differ significantly by sex (Fig 2C, Kruskal-Wallis Rank Sum Test, $p=0.333$ ). Bacterial and total DNA concentrations were significantly correlated (S1 A Fig, $\mathrm{R}=0.42, p=<0.001$ ), and 15 samples were identified as having greater bacterial DNA concentrations than total DNA concentrations (S2 Table).

\section{Bacterial diversity by extraction method, dog, and sex}

Based on decontam (R package, v.1.10.0), we bioinformatically removed a total of 28 putative contaminant ASVs (S5 Table). We also removed all sequences identified as chloroplasts, mitochondria, eukaryotes, and archaea. Additionally, four samples with fewer than 300 reads were excluded from 16S rRNA bacterial community analyses (S2 Table). Three of these four samples came from $\operatorname{dog} \mathrm{CB}$, who had one of the lowest urine bacterial concentrations. Three of the 5 negative controls also had fewer than 300 reads while the remaining 2 negative controls had $7,899(\mathrm{MB})$ and 6,936 (BTL) reads. Over $99 \%$ of the reads in the MB negative control were aligned to the same ASV (M. plutonius) that was spiked into our positive controls. No total or bacterial DNA was recovered from this sample after extraction, so we attribute the presence of the positive control taxa in this sample to potential cross contamination during DNA plating, library preparation, or sequencing. The BTL negative control with 6,936 reads contained a total of 122 ASVs, but none of these ASVs were identified in any other sample. The remaining samples ranged from 316 to 42,090 reads (average $=14,721$ ). A total of 51 samples were retained for analysis. The number of $16 \mathrm{~S}$ rRNA reads per sample differed significantly by dog (Kruskal-Wallis, $p=<0.001$ ), but not by sex (Kruskal-Wallis, $p=0.937$ ) or extraction method (Kruskal-Wallis, $p=0.378$ ); although, B yielded the greatest number of $16 \mathrm{~S}$ reads per sample (S2 Fig). There was also a significant correlation between the number of $16 \mathrm{~S}$ reads and bacterial DNA concentrations ( $\mathrm{S} 1 \mathrm{~B}$ Fig, $\mathrm{R}=0.28, p=0.047$ ).

Bacterial diversity was compared across samples by extraction method, dog, and sex (Shannon Index: Fig 3; Observed Features and Simpson Index: S3 Fig). The positive control, which was urine from female dog AW spiked with M. plutonius, was removed from all analyses by sex to prevent bias. All three measures of diversity revealed the same patterns. Bacterial

$\mathbf{a}$ b

c
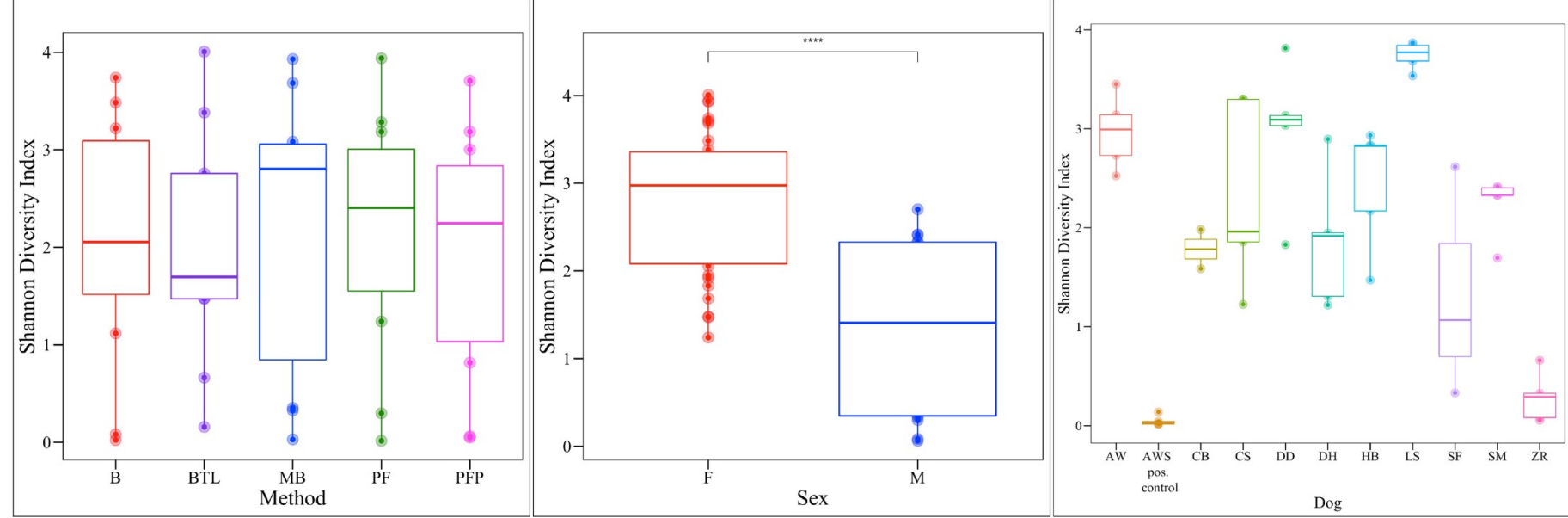

Fig 3. Bacterial diversity. The Shannon diversity metric was used to compare bacterial diversity by (a) extraction method, (b) sex, (c) and dog. Bacterial diversity did not differ significantly by kit (Kruskal-Wallis, $p=0.951$ ) but did differ significantly by dog (Kruskal-Wallis, $p=<0.001$ ). For all statistically significant pairwise comparisons by dog, see S6 Table. Females exhibited higher bacterial diversity than males (Kruskal-Wallis, $p=<0.001$ ). B $=$ Bacteremia, BTL $=$ Blood \& Tissue with Lysozyme, $\mathrm{MB}=$ Magnetic Beads, $\mathrm{PF}=$ PowerFecal $^{\mathbb{R}}, \mathrm{PFP}=$ PowerFecal $^{\mathbb{R}}$ Pro, $\mathrm{F}=$ Female, $\mathrm{M}=$ Male. 
diversity did not differ by extraction method (Kruskal-Wallis: Shannon, $p=0.951$; Observed Features, $p=0.751$, Simpson, $p=0.872$; Fig $3 \mathrm{~A}$ and S3A and S3D Fig) but did differ significantly by sex (Kruskal-Wallis: Shannon, $p=<0.001$; Observed Features, $p=0.005$, Simpson, $p$ $=<0.001$; Fig 3B and S3B and S3E Fig) and by dog (Kruskal-Wallis: Shannon, $p=<0.001$; Observed Features, $p=<0.001$, Simpson, $p=<0.001$; Fig $3 \mathrm{C}$ and S3C and S3F Fig and S6 Table). Females had significantly higher bacterial diversity than males across all diversity metrics. By dog, LS had significantly higher bacterial diversity than 9 other dogs while ZR had significantly lower bacterial diversity than 9 other dogs. For a full list of significant pairwise comparisons by dog, see S6 Table.

\section{Bacterial composition by extraction method, dog, and sex}

Bray Curtis (Fig 4) and Unweighted and Weighted UniFrac metrics (S4 Fig) were used to compare bacterial composition (beta-diversity) across groups. No significant differences were observed by extraction method (PERMANOVA: Bray Curtis, $p=1.000$; Unweighted UniFrac, $p=0.539$; Weighted UniFrac, $p=0.743$, Fig 4A and S4A and S4D Fig). However, bacterial composition did differ significantly by sex (PERMANOVA: Bray Curtis, $p=<0.001$, Unweighted UniFrac, $p=0.003$; Weighted UniFrac, $p=0.02$ Fig $4 \mathrm{~B}$ and S4B and S4E Fig) and by dog (PERMANOVA: Bray Curtis, $p=<0.001$, Unweighted UniFrac, $p=<0.001$; Weighted UniFrac, $p=<0.001$; Fig $4 \mathrm{C}$ and S4C and S4F Fig and S7 Table).

\section{Bacterial taxonomic differences by extraction method, dog, and sex}

In total, there were 23 phyla, 318 genera, and 206 amplicon sequence variants (ASVs, roughly equivalent to species) observed across all canine urine samples. Collectively, the three most abundant phyla across all samples were Proteobacteria, Firmicutes, and Bacteroidetes (Fig 5). We also noted that the positive control sample, AWS, which was urine from dog AW spiked with $M$. plutonius, had significantly lower bacterial diversity (Shannon, Wilcoxon Rank Sum test, $p=<0.001$ ) as compared to AW. This indicates that in urine dominated by a specific microbe (e.g. during a urinary tract infection), amplicon sequencing precludes the ability to detect other microbes present in the bacterial community. At the phyla level, there were no

a

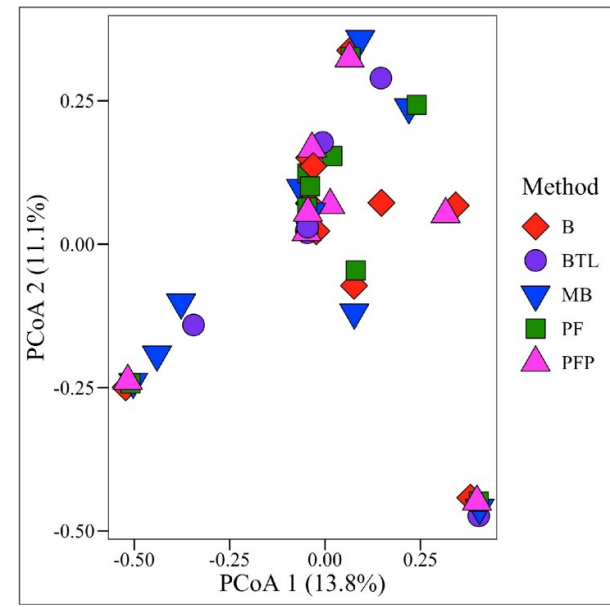

b

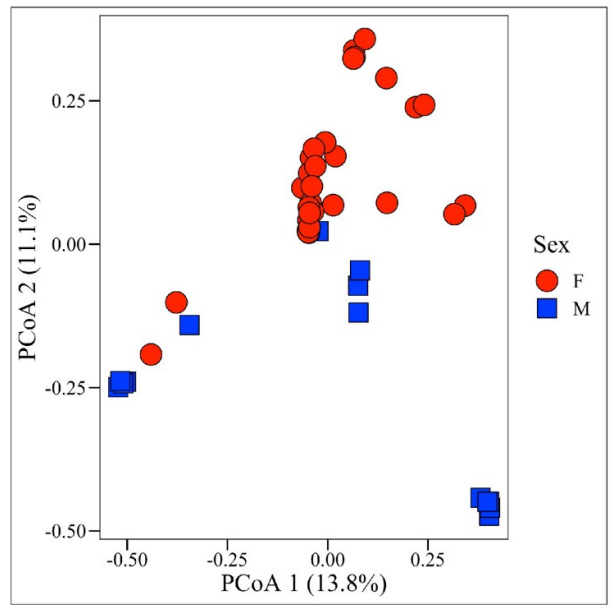

c

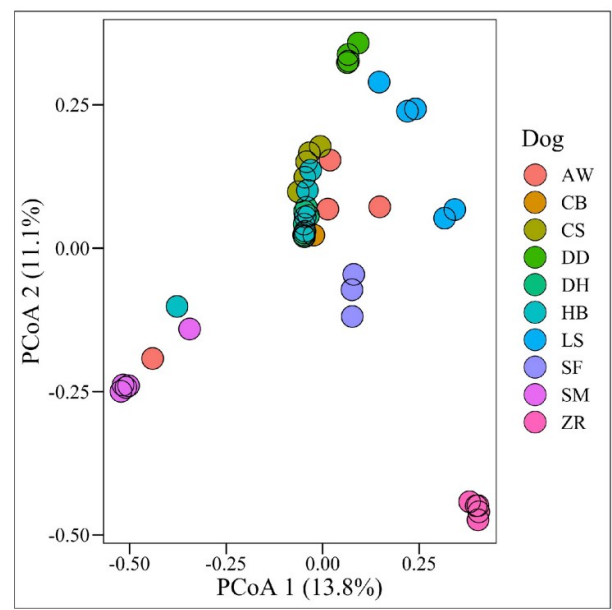

Fig 4. Bacterial composition. Bray Curtis dissimilarity matrices were used to compare bacterial composition (beta-diversity) by (a) extraction method, (b) sex, (c) and dog. Bacterial composition did not differ significantly by method (PERMANOVA, $p=1.000$ ) but did differ significantly by sex (PERMANOVA, $p=<0.001$ ) and dog (PERMANOVA, $p=<0.001$ ). 
$\mathbf{a}$

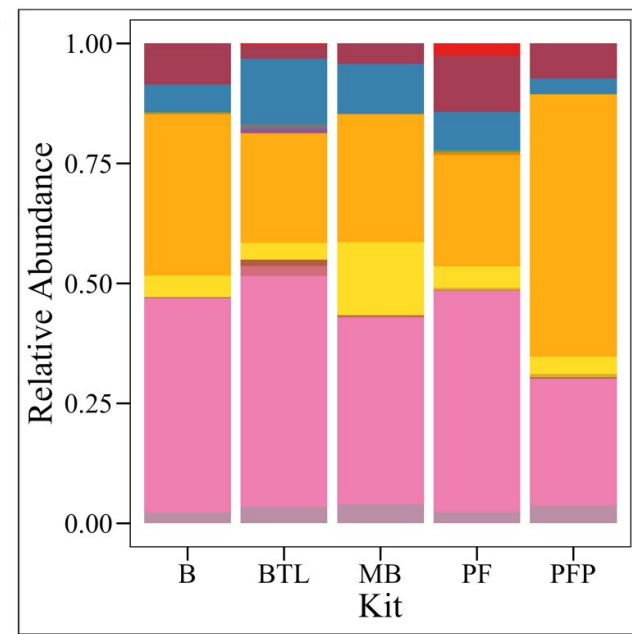

b

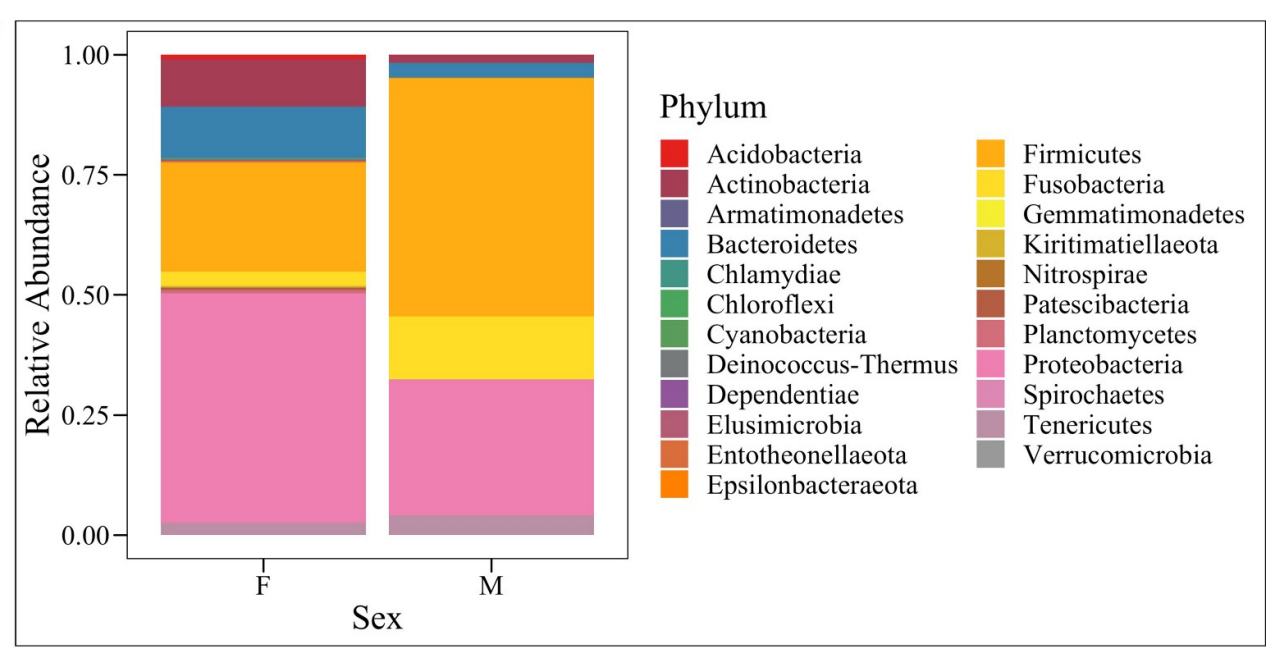

c

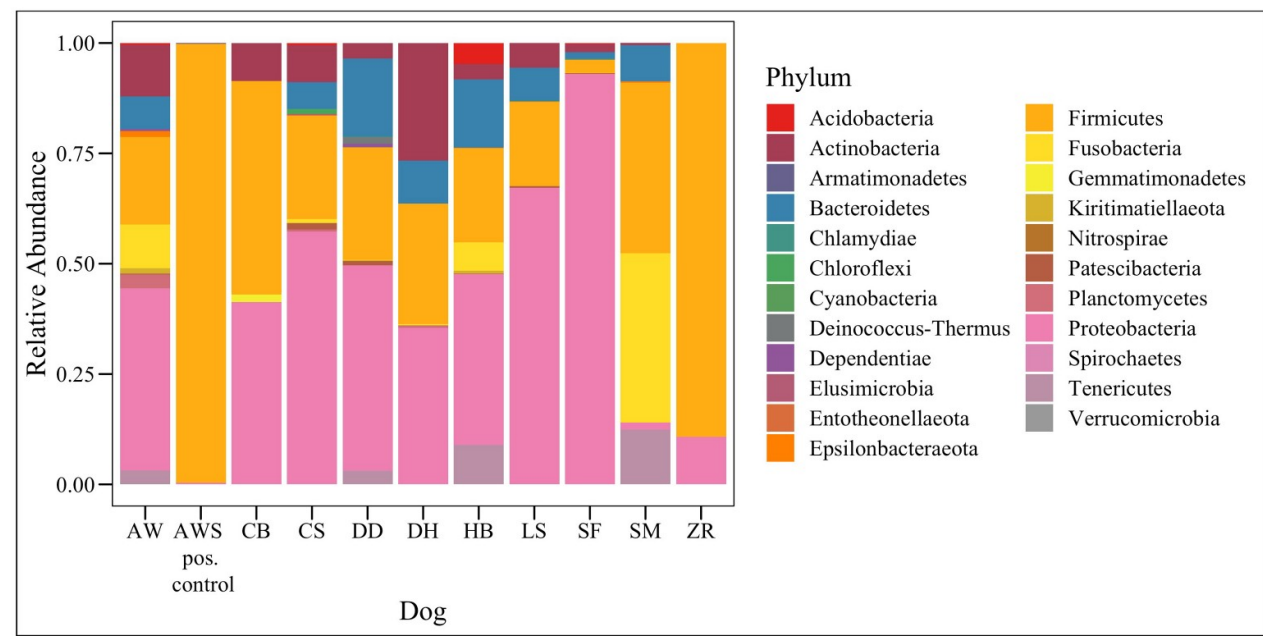

Fig 5. Bacterial relative abundances by phyla. Bacterial taxa bar plots by Phyla for (a) extraction method, (b) sex and (c) dog. $\mathrm{B}=$ Bacteremia, $\mathrm{BTL}=$ Blood Tissue with Lysozyme, $\mathrm{MB}=$ Magnetic Beads, $\mathrm{PF}=$ PowerFecal $^{\circledR}$, PFP $=$ PowerFecal ${ }^{\mathbb{R}}$ Pro, $\mathrm{F}=$ Female, $\mathrm{M}=$ Male

https://doi.org/10.1371/journal.pone.0253989.g005
Phylum

Acidobacteria

Armatimonadetes

Bacteroidetes

Chlamydiae

Chloroflexi

Cyanobacteria

Deinococcus-Thermu

Dependentiae

Elusimicrobia

Entotheonellaeota

Epsilonbacteraeota
Firmicutes

Fusobacteria

Gemmatimonadetes

Kiritimatiellaeota

Nitrospirae

Patescibacteria

Planctomycetes

Proteobacteria

Spirochaetes

Tenericutes

Verrucomicrobia
Patescibacteria

anctomycetes

rochaetes

Tenericutes

Entotheonellaeota

Epsilonbacteraeot 
$\mathbf{a}$

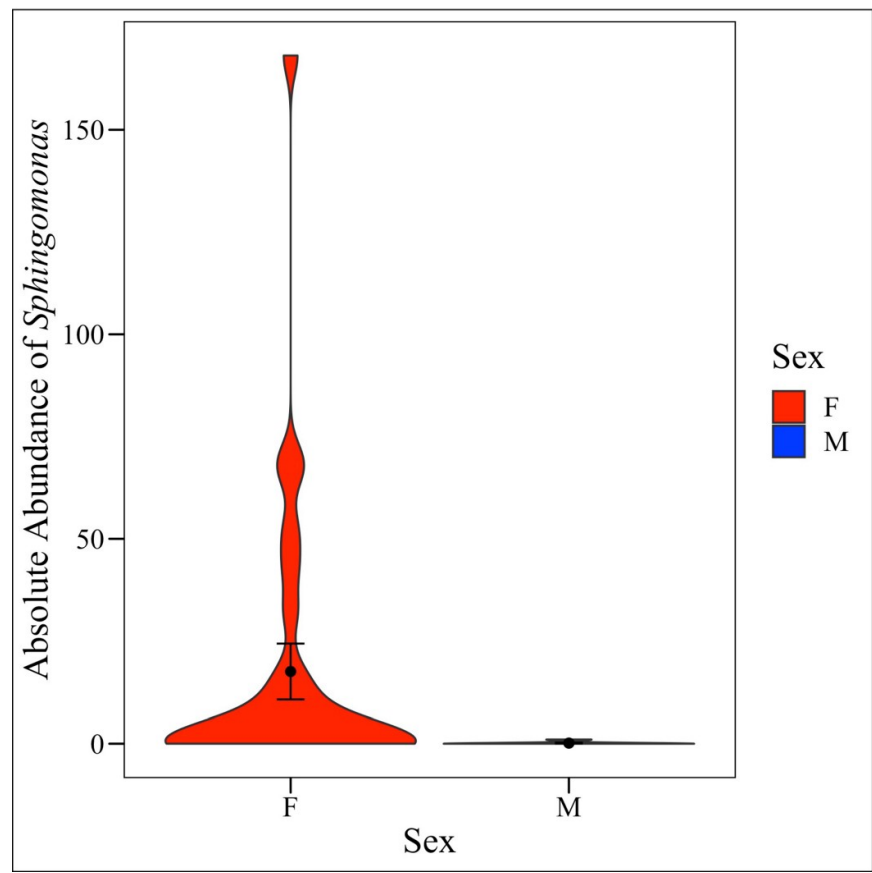

b

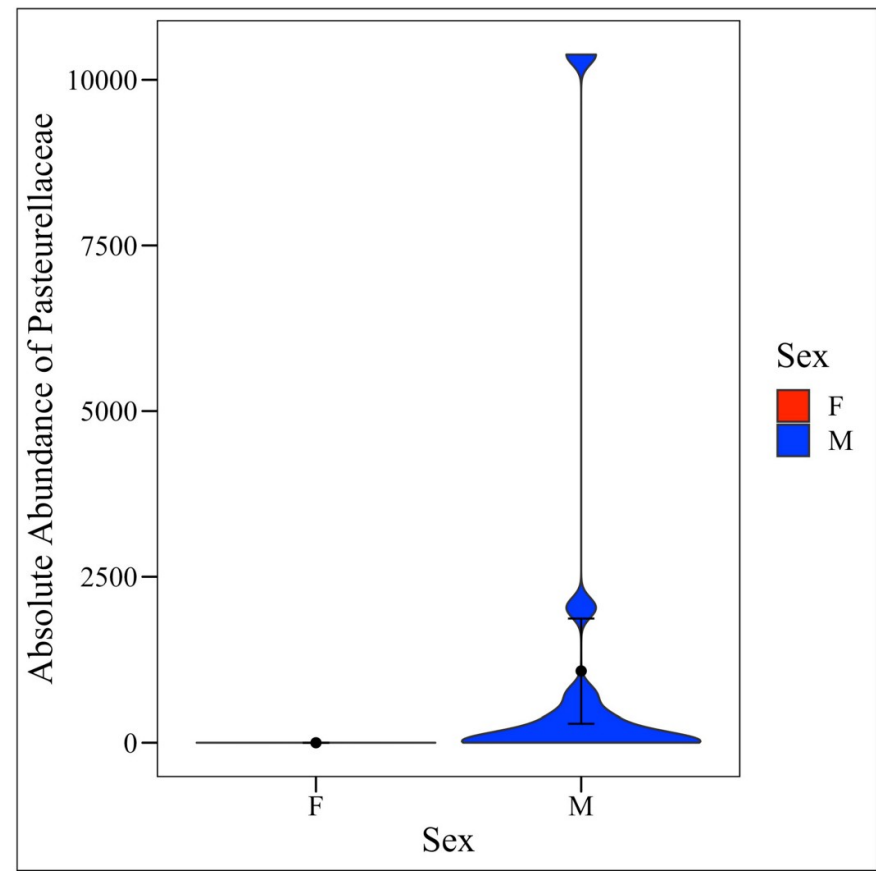

Fig 6. Differentially abundant taxa by sex. (a) Females had significantly greater absolute cell counts of Sphingomonas (Kruskal-Wallis, $p=0.0066)$ while (b) males had significantly greater absolute cell counts of Pasteurellaceae bacterium canine oral taxon 272 (Kruskal-Wallis, $p=<0.001$ ). Only samples with $>300$ reads and at least 2 qPCR replicates are included in this figure.

https://doi.org/10.1371/journal.pone.0253989.g006

significant differences in taxa abundances by extraction method (Fig 5A, Kruskal-Wallis, $p=0.81$ ) but there were by sex (Fig 5 B, Kruskal-Wallis, $p=0.02$ ), and dog (Fig 5 C, KruskalWallis, $p=<0.01$ ). By sex, females had a significantly higher abundance of Actinobacteria as compared to males (Fig 5B, ANCOM, $W=20$ ). At the L7 (roughly species) level, no taxa were found to be differentially abundant by extraction method. However, several taxa were identified as differentially abundant by sex and by dog. By sex, the relative abundance of Sphingomonas was significantly increased in females compared to males (S5A Fig, ANCOM $W=579$ ) while Pasteurellaceae bacterium canine oral taxon 272 was significantly more abundant in males (S5B Fig, ANCOM $W=596$ ). Thirty-two taxa (L7 level) were differentially abundant by dog (S8 Table, ANCOM).

Per Nadkarni et al. (2002), we then converted the relative abundances into estimated absolute cell counts using bacterial DNA concentrations derived from qPCR and using the weight of DNA in one E. coli cell (4.96 fg) as a standard [70]. This conversion calculation assumes that there is one copy of the $16 \mathrm{~S}$ rRNA gene in each bacteria and that the molecular weight of DNA in bacterial cells of all taxa is $4.96 \mathrm{fg}$ per cell. In fact, $16 \mathrm{~S}$ copy number and molecular weight varies widely between taxa; however, Nadkarni et al. found these assumptions to be reasonable when comparing cultured cell counts to cell counts based on qPCR [70]. Total cell counts ranged from approximately 10-147,072 cells per sample. We then multiplied total cell counts by the relative abundances of Sphingomonas or Pasteurellaceae bacterium canine oral taxon 272 to get estimated absolute cell counts of these taxa. The absolute cell counts of Sphingomonas were significantly increased in females (Fig 6A, Kruskal-Wallis, $p=0.0066$ ) while the absolute cell counts of Pasteurellaceae bacterium canine oral taxon 272 were significantly increased in males (Fig 6B, Kruskal-Wallis, $p=<0.001$ ). (Note: only samples with $>300$ reads and at least $2 \mathrm{qPCR}$ replicates were included in this analysis). 


\section{Discussion}

We compared total and bacterial DNA concentrations as well as $16 \mathrm{~S}$ rRNA bacterial community sequencing data from the urine of 10 healthy dogs extracted using 5 different DNA isolation methods. Each method employed various mechanical, chemical, and / or thermal lysing techniques. Sex and dog, but not extraction method, significantly affected DNA concentrations and bacterial diversity and composition. The B kit was determined to be one of the most effective methods for urine bacterial DNA extraction.

\section{DNA concentrations and $16 S$ reads}

The $\mathrm{B}$ kit extracted the greatest total and bacterial DNA concentrations from the canine urine samples (Figs 1B and 2B). Moreover, B extracted quantifiable bacterial DNA from the greatest number of samples (10 urine samples, including the positive control) while BTL extracted quantifiable total DNA from the greatest number of samples ( 9 urine samples, including the positive control) (Figs 1A and 2A). Additionally, males contained significantly greater total but not bacterial DNA as compared to females (Figs 1C and 2C). Total and bacterial DNA concentrations and number of $16 \mathrm{~S}$ rRNA reads also varied significantly by dog (Figs 1D and 2D and S2C Fig and S3 \& S4 Tables). B also produced the greatest number of 16S rRNA reads as compared to other extraction methods (Kruskal-Wallis, $p=0.378$ ); however, as $16 \mathrm{~S}$ rRNA sequencing data are compositional, we do not weigh this finding heavily [81] (S2A Fig). Taken together, B demonstrated efficacy over other methods in extracting DNA from dog urine, while biological factors such as sex and dog had strong effects on DNA concentrations.

In 15 samples, bacterial DNA concentrations were greater than total DNA concentrations, and in several of these cases, no DNA was detected by Qubit while bacterial DNA was amplified via $\mathrm{qPCR}$. This could be due to relatively high bacterial loads in these dogs, and the increased sensitivity of qPCR (bacterial DNA concentrations) as compared to Qubit (total DNA concentrations) [82]. In 9 other samples, 5 of which were extracted by BTL (S2 Table), there was quantifiable total DNA but no quantifiable bacterial DNA detected, suggesting that these samples may have contained more host than bacterial DNA, or that BTL was more effective in extracting host as compared to bacterial DNA. Despite the lack of quantifiable bacterial DNA in these samples, we obtained 16S rRNA sequencing reads from all 9 samples; although, 3 of these samples were excluded from 16S rRNA analysis for having fewer than 300 reads. This indicates that $16 \mathrm{~S}$ rRNA sequencing may be more sensitive to bacterial DNA than qPCR [83]; however, the bacterial taxa present in these samples should be reviewed carefully for potential contamination as they could contain low reads and skewed relative abundances. Alternately, the different primer sets used in qPCR and 16S rRNA sequencing, although both considered "universal bacterial primers," may contribute to the differences we observed in bacterial DNA detection between qPCR and $16 \mathrm{~S}$ rRNA sequencing.

\section{Bacterial diversity and composition}

Bacterial diversity and composition differed significantly by sex and dog but not extraction method (Figs 3 and 4), indicating that individual differences in the urine microbiota overwhelmed potential differences introduced by extraction. A total of four samples were excluded from bacterial community analysis for having fewer than 300 reads. All canine urine samples extracted via $\mathrm{B}$ and $\mathrm{PF}$ (excluding negative controls) contained greater than 300 reads and were retained for analysis. These results again highlight $\mathrm{B}$ as a viable extraction method for urine microbiota, as it did not obviously skew bacterial communities while also generating reasonable $16 \mathrm{~S}$ rRNA yields. We further observed that urine microbiota were highly variable between individuals, a finding that has been reported previously in studies on human and 
canine urine $[9,10,13,25]$. A few dogs stood out in terms of bacterial composition and diversity. ZR, for example, had significantly lower bacterial diversity (Shannon) than most other dogs while LS had significantly higher diversity than most dogs (S6 Table). Both ZR and LS also had significantly different bacterial composition (Bray-Curtis) than most other dogs (S7 Table).

We also observed that the samples from females had significantly higher bacterial diversity than the samples from males despite males having higher total (Fig 1C) and bacterial DNA concentrations (Fig 2C). This suggests that males may be shedding more host cells into urine than females. The increased urine bacterial diversity in the samples from females could be due to differing anatomy between sexes, differing hormone profiles, or differing urination habits. In humans, urine microbial diversity results vary by study. In a 2013 study based on free-catch urine, increased diversity was reported in healthy females as compared to males [32], while in a study from 2020 that compared both free-catch and catheterized urine, no differences in microbial diversity were reported between males and females [12]. The literature on canine urine microbiota is limited. There are only two studies, to our knowledge, on the healthy canine urine microbiota. Both employed cystocentesis for sampling, and microbial diversity did not differ by sex $[56,57]$. Hormones have also been linked to changes in the fecal microbiome of women and could feasibly be altering the urine microbiota [84]. In addition, urinary behavior differs between male and female dogs with males urinating more frequently than females [85]. It is feasible that urine volume and retention time in the bladder could alter urine composition and the urine microbial community.

\section{Taxonomic differences}

In this study, the three most abundant phyla across all samples were Proteobacteria, Firmicutes, and Bacteroidetes. Other studies on urine microbiota in humans and in dogs report similar findings [10, 32, 33, 86, 87]. There were no differentially abundant taxa at the phyla level by extraction method or dog. By extraction method, Proteobacteria was the most abundant phyla in samples extracted by B (44.7\%), BTL (48.0\%), MB (38.8\%), and PF (46.2\%) while Firmicutes was most abundant in samples extracted by PFP (54.6\%). We also observed a few rare taxa that were only detected by one or two methods: Taxa in the phyla Dependentiae were only observed in samples extracted by BTL while Chlamydiae was only observed in samples extracted by B or BTL. Acidobacteria were only detected in sample extracted by B $(0.012 \%)$, BTL (0.96\%), and PF (2.59\%). These differences, while not statistically significant, suggest potential biological differences-or biases-by kit. Extraction method biases in the lysis and detection of gram-positive versus gram-negative bacteria has been reported previously, and continued evaluation of kit biases in urine microbiota studies is warranted [61].

By sex, the relative abundance of Actinobacteria was significantly higher in the samples from females than in the samples from males. Actinobacteria has also been reported in the urine of human females $[6,10,32,33,87]$, and in the oral [88] and gut $[89,90]$ microbiota of dogs. At the L7 (roughly species) level, we observed several differentially abundant taxa by sex and by dog, but not by extraction method. Notably, Pasteurellaceae bacterium canine oral taxon 272 was significantly increased in the samples from males while Sphingomonas was significantly increased in the samples from females. Taxa in the Pasteurellaceae family have been reported as part of the canine oral [88, 91, 92], nasal [93], and gut microbiota [94]. It is possible that this taxon is introduced into canine urine through licking of the prepuce or penis. As such, this taxon could represent a skin contaminant or could be a true inhabitant of canine urine. Similarly, Sphingomonas has been reported in the canine vaginal microbiota [56] and could represent a genital contaminant or true inhabitant of urine. In humans, Lactobacillus 
species are common vaginal microbes, but studies on urine microbiota collected via catheter demonstrate that similar or identical Lactobacillus species are also present and culturable from the bladder and are not just contaminants $[6,95,96]$.

There were several limitations to the work performed here. First, mid-stream free-catch urine was used for this study. This collection technique is highly relevant as it is non-invasive and commonly employed in canine health assessments; however, it is subject to contamination by urethral, genital, and skin microbiota. Cystocentesis is another method of sampling urine directly from the bladder, and it reduces the potential for genital and skin contaminants. In one previous study on healthy canine urine sampled via cystocentesis, no significant differences in microbiota were observed between male and female dogs [56]. In contrast, our study observed several differences in bacterial composition and diversity by sex. These differences could be attributed to genital (e.g. vaginal) or skin bacteria that are captured in free-catch urine. A second limitation is that we cannot determine if the DNA and sequences detected in urine samples came from live or dead bacteria. In other words, we may be detecting microbes that are not actually contributing to the urogenital environment. Specialized culture or assessments of microbial function (e.g. metabolomics, proteomics, transcriptomics) are necessary to make this distinction. Third, we did not assess spay / neuter status, age, diet, or breed in relation to the urine microbiota as we were not powered to make these comparisons (S1 Table). However, these variables could very well be linked to alterations in microbiota and future studies parsing out these relationships will be necessary.

In this study, we selected the four most commonly used DNA extraction methods across 53 published studies on the urine microbiota. We also included the PFP kit as it was designed by the manufacturer to replace the older PF kit, which was identified as one of the top four extraction methods. Notably, new kits optimized for low biomass extractions and even urine DNA isolation (e.g. Norgen) continue to emerge on the market and should be tested in future studies. We also made a few modifications to the manufacturer protocols which could alter bacterial profile results. Specifically, for all extraction methods that involved bead beating (B, PF, PFP), we performed two rounds of bead beating for 60 seconds at $6 \mathrm{~m} / \mathrm{s}$ on an MP FastPrep 24. This differs from the instrumentation and/or timing listed in the protocols, but we wanted to ensure consistent bead beating across all methods as bead beating time and intensity can have an effect on bacterial community composition [97]. Finally, these samples were analyzed using $16 \mathrm{~S}$ rRNA sequencing. We did this to ensure that we could obtain valid sequencing data from a relatively small amount of urine $(3 \mathrm{ml})$. Now that we have established an effective method for urine microbiota extraction, we can pursue deeper sequencing (e.g. whole shotgun metagenomic sequencing) to more fully characterize bacterial genomes and potential bacterial function. Other studies on the urine microbiota have used a range of urine volumes from $1 \mathrm{ml}$ $[11,12,98]$ to $30 \mathrm{ml}[56,99]$. We opted to test smaller volumes of urine as it is not always feasible to obtain $30 \mathrm{ml}$ of urine from a dog, particularly a small dog. Moreover, future multi-omic studies may require aliquoting of a single urine sample for multiple analyses (e.g. urinalyses, culture, microbiome sequencing, metabolomics, protein analysis, etc.), and optimizing DNA extractions with minimal input can facilitate this. Using larger volumes of urine may yield larger DNA concentrations, which could more readily facilitate deeper sequencing of these samples.

\section{Conclusion}

The Bacteremia (B) kit yielded the highest total DNA concentrations, the highest bacterial DNA concentrations, the greatest number of $16 \mathrm{~S}$ rRNA sequencing reads, and it extracted bacterial DNA from the greatest number of samples. Moreover, bacterial diversity and 
composition did not significantly differ by kit indicating that no method, including B, dramatically biased the sequencing results. As such, Bacteremia (B) proved effective as an extraction method for studies of the urine microbiota.

\section{Supporting information}

S1 Fig. Correlation analyses. Correlation between (a) total and bacterial DNA concentrations and (b) the number of $16 \mathrm{~S}$ rRNA sequencing reads and bacterial DNA concentrations. (TIF)

S2 Fig. 16S rRNA sequencing reads. The number of $16 \mathrm{~S}$ reads per sample was compared by (a) extraction method, (b) sex, and (c) dog. There were no significant differences in the number of reads by method (Kruskal-Wallis, $p=0.378$ ) and sex (Kruskal-Wallis, $p=0.937$ ) but there was a significant difference in the number of reads by $\operatorname{dog}$ (Kruskal-Wallis, $p=$ $<0.00001)$.

S3 Fig. Bacterial diversity. Observed Features and the Simpson index were used to compare microbial diversity by extraction method $(\mathbf{a}, \mathbf{d}), \operatorname{sex}(\mathbf{b}, \mathbf{e})$, and $\operatorname{dog}(\mathbf{c}, \mathbf{f})$. Microbial diversity did not differ by extraction method (Kruskal-Wallis; Observed Features, $p=0.751$; Simpson Index, $p=0.872$ ) but did differ by dog (Kruskal-Wallis; Observed Features, $p=<0.001$; Simpson Index, $p=<0.001$ ). For all statistically significant pairwise comparisons by dog, see $\mathrm{S} 6$ Table. Females exhibited significantly higher microbial diversity than males (Kruskal-Wallis: Observed Features, $p=0.005$; Simpson, $p=<0.001$ ). B $=$ Bacteremia, BTL $=$ Blood Tissue with Lysozyme, $\mathrm{MB}=$ Magnetic Beads, $\mathrm{PF}=$ PowerFecal ${ }^{\mathbb{R}}$, PFP $=$ PowerFecal ${ }^{\mathbb{R}}$ Pro, $\mathrm{F}=$ Female, $\mathrm{M}=$ Male.

S4 Fig. Bacterial composition. Unweighted $(\mathbf{a}-\mathbf{c})$ and Weighted UniFrac matrices (beta-diversity) (d-f) comparing microbial composition by (a, d) extraction method, (b, e) sex, (c, f) and dog. Microbial composition did not differ significantly by extraction method (Kruskal-Wallis: Unweighted UniFrac, $p=0.539$; Weighted UniFrac, $p=0.743$ ) but did differ significantly by sex (Kruskal-Wallis: Unweighted UniFrac, $p=0.003$; Weighted UniFrac, $p=0.03$ ) and dog (Kruskal-Wallis: Unweighted UniFrac, $p=<0.001$; Weighted UniFrac, $p=<0.001$ ) (TIF)

S5 Fig. Differentially abundant taxa by sex. (a) Females had significantly greater relative abundances of Sphingomonas (ANCOM, $W=579$ ) while $(\mathbf{b})$ males had significantly greater relative abundances of Pasteurellaceae bacterium canine oral taxon 272 (ANCOM, $W=596$ ). (TIF)

S1 Table. Dog metadata. Sex, age, and breed of dogs enrolled in this study. (DOCX)

S2 Table. Sample concentrations and reads. Total and bacterial DNA concentrations and number of $16 \mathrm{~S}$ reads in each sample. (16S read counts are reported both before and after running "decontam," an R package that identifies and removes potential contaminant taxa.) $\mathrm{B}=$ Bacteremia, $\mathrm{BTL}=$ Blood \& Tissue with Lysozyme, $\mathrm{MB}=$ Magnetic Beads,

$\mathrm{PF}=$ PowerFecal ${ }^{\circledR}, \mathrm{PFP}=$ PowerFecal $^{\circledR}$ Pro. ${ }^{*}=$ Excluded from qPCR analysis as only one replicate amplified in qPCR. ${ }^{* *}=$ Variation between replicates was greater than $3 \%$ but samples were included in analysis. ${ }^{* * *}$ Excluded from $16 \mathrm{~S}$ analysis for having $<300$ reads. Blue 
highlights = no bacterial DNA detected although total DNA was detected. (XLSX)

S3 Table. Total DNA concentration pairwise comparisons by dog. P-values based on Wilcoxon Rank Sum Tests for total DNA concentrations using 1000 permutations and False Discovery Rate corrections. There were no statistically significant pairwise comparisons.

(DOCX)

S4 Table. Bacterial DNA concentration pairwise comparisons by dog. P-values based on Wilcoxon Rank Sum Tests for total DNA concentrations using 1000 permutations and False Discovery Rate corrections. There were no statistically significant pairwise comparisons. (DOCX)

S5 Table. ASVs identified as contaminants. We employed both the frequency and prevalence methods in the R package decontam v.1.10.0 to identify putative contaminant ASVs. In total, 28 ASVs were identified and excluded from our analysis as contaminants.

(DOCX)

S6 Table. Alpha-diversity pairwise comparisons by dog. P-values resulting from pairwise Wilcoxon Rank Sum Tests for alpha diversity metrics using 1000 permutations and False Discovery Rate corrections. * $\mathrm{p}<0.05$.

(DOCX)

S7 Table. Beta-diversity pairwise comparisons by dog. P-values based on PERMANOVA pairwise comparisons using 1000 permutations False Discovery Rate corrections. ${ }^{*} \mathrm{p}<0.05$. (DOCX)

S8 Table. Differentially abundant taxa by dog. Thirty-two taxa at the L7 level were differentially abundant by $\mathrm{dog}$.

(DOCX)

\section{Acknowledgments}

We are grateful to Dr. Sushmitha Durgam for the shared used of her qPCR instrument and to the many dogs and dog owners who participated in this study. We also acknowledge the Ohio Supercomputer Center (Columbus, Ohio, established 1987) for the high performance computing resources used in this study.

\section{Author Contributions}

Conceptualization: Vanessa L. Hale.

Data curation: Ryan Mrofchak, Christopher Madden, Morgan V. Evans, Vanessa L. Hale.

Formal analysis: Ryan Mrofchak, Christopher Madden, Morgan V. Evans, Vanessa L. Hale.

Funding acquisition: Vanessa L. Hale.

Investigation: Ryan Mrofchak, Christopher Madden.

Methodology: Ryan Mrofchak, Christopher Madden, Morgan V. Evans.

Project administration: Christopher Madden.

Resources: Vanessa L. Hale.

Supervision: Christopher Madden, Vanessa L. Hale. 
Validation: Vanessa L. Hale.

Visualization: Ryan Mrofchak, Vanessa L. Hale.

Writing - original draft: Ryan Mrofchak, Christopher Madden, Vanessa L. Hale.

Writing - review \& editing: Ryan Mrofchak, Christopher Madden, Morgan V. Evans, Vanessa L. Hale.

\section{References}

1. Thomas-White K, Brady M, Wolfe AJ, Mueller ER. The bladder is not sterile: History and current discoveries on the urinary microbiome. Curr BI Dysfunct reports BI Dysfunct reports [Internet]. 2016/01/30. 2016 Mar; 11(1):18-24. Available from: https://www.ncbi.nlm.nih.gov/pubmed/27182288

2. Kass EH. Pyelonephritis and bacteriuria. A major problem in preventive medicine. Ann Intern Med. 1962; 56:46-53. https://doi.org/10.7326/0003-4819-56-1-46 PMID: 14454174

3. Maskell RM. The natural history of urinary tract infection in women. Med Hypotheses. 2010; 74(5):8026. https://doi.org/10.1016/j.mehy.2009.12.011 PMID: 20064694

4. Maskell R, Allen J, Pead L. The puzzle of "Urethral syndrome": a possible answer? Lancet. 1979; 313 (8125):1058-9. https://doi.org/10.1016/s0140-6736(79)92953-2 PMID: 86778

5. Thapaliya J, Khadka P, Thapa S, Gongal C. Enhanced quantitative urine culture technique, a slight modification, in detecting under-diagnosed pediatric urinary tract infection. BMC Res Notes. 2020; 13 (5). https://doi.org/10.1186/s13104-019-4875-y PMID: 31900212

6. Thomas-White K, Forster SC, Kumar N, Van Kuiken M, Putonti C, Stares MD, et al. Culturing of female bladder bacteria reveals an interconnected urogenital microbiota. Nat Commun. 2018; 9(1557). https:// doi.org/10.1038/s41467-018-03968-5 PMID: 29674608

7. Price TK, Dune T, Hilt EE, Thomas-White KJ, Kliethermes S, Brincat C, et al. The clinical urine culture: Enhanced techniques improve detection of clinically relevant microorganisms. J Clin Microbiol. 2016; 54(5):1216-22. https://doi.org/10.1128/JCM.00044-16 PMID: 26962083

8. Dune TJ, Price TK, Hilt EE, Thomas-White KJ, Kliethermes S, Brincat C, et al. Urinary symptoms and their associations with urinary tract infections in urogynecologic patients. Obstet Gynecol. 2017; 130 (4):718-25. https://doi.org/10.1097/AOG.0000000000002239 PMID: 28885414

9. Wolfe AJ, Toh E, Shibata N, Rong R, Kenton K, FitzGerald MP, et al. Evidence of uncultivated bacteria in the adult female bladder. J Clin Microbiol. 2012; 50(4):1376-83. https://doi.org/10.1128/JCM.0585211 PMID: 22278835

10. Pearce MM, Hilt EE, Rosenfeld AB, Zilliox MJ, Thomas-White K, Fok C, et al. The female urinary microbiome: A comparison of women with and without urgency urinary incontinence. MBio. 2014; 5(4): e01283-14. https://doi.org/10.1128/mBio.01283-14 PMID: 25006228

11. Price TK, Hilt EE, Thomas-White K, Mueller ER, Wolfe AJ, Brubaker L. The urobiome of continent adult women: a cross-sectional study. BJOG An Int J Obstet Gynaecol. 2020; 127(2):193-201.

12. Pohl HG, Groah SL, Pérez-Losada M, Ljungberg I, Sprague BM, Chandal N, et al. The Urine Microbiome of Healthy Men and Women Differs by Urine Collection Method. Int Neurol J. 2020; 24(1):41-51. https://doi.org/10.5213/inj.1938244.122 PMID: 32252185

13. Hilt EE, McKinley K, Pearce MM, Rosenfeld AB, Zilliox MJ, Mueller ER, et al. Urine Is Not Sterile: Use of Enhanced Urine Culture Techniques To Detect Resident Bacterial Flora in the Adult Female Bladder. Munson E, editor. J Clin Microbiol [Internet]. 2014 Mar 1; 52(3):871-6. Available from: http://jcm.asm. org/content/52/3/871.abstract https://doi.org/10.1128/JCM.02876-13 PMID: 24371246

14. Chen Z, Phan MD, Bates LJ, Peters KM, Mukerjee C, Moore KH, et al. The urinary microbiome in patients with refractory urge incontinence and recurrent urinary tract infection. Int Urogynecol J. 2018; 29(12):1775-82. https://doi.org/10.1007/s00192-018-3679-2 PMID: 29946828

15. Fettweis JM, Serrano MG, Brooks JPL, Edwards DJ, Girerd PH, Parikh HI, et al. The vaginal microbiome and preterm birth. Nat Med. 2019; 25:1012-1021. https://doi.org/10.1038/s41591-019-0450-2 PMID: 31142849

16. Ravel J, Gajer P, Abdo Z, Schneider GM, Koenig SSK, McCulle SL, et al. Vaginal microbiome of reproductive-age women. Proc Natl Acad Sci U S A. 2011; 108(Supp. 1). https://doi.org/10.1073/pnas. 1002611107 PMID: 20534435

17. Griffen AL, Beall CJ, Campbell JH, Firestone ND, Kumar PS, Yang ZK, et al. Distinct and complex bacterial profiles in human periodontitis and health revealed by 16 S pyrosequencing. ISME J. 2012; 6 (6):1176-85. https://doi.org/10.1038/ismej.2011.191 PMID: 22170420 
18. Erb-Downward JR, Thompson DL, Han MK, Freeman CM, McCloskey L, Schmidt LA, et al. Analysis of the lung microbiome in the "healthy" smoker and in COPD. PLoS One. 2011; 6(2):e16384. https://doi. org/10.1371/journal.pone.0016384 PMID: 21364979

19. Manor O, Dai CL, Kornilov SA, Smith B, Price ND, Lovejoy JC, et al. Health and disease markers correlate with gut microbiome composition across thousands of people. Nat Commun. 2020; 11(5206). https://doi.org/10.1038/s41467-020-18871-1 PMID: 33060586

20. David LA, Maurice CF, Carmody RN, Gootenberg DB, Button JE, Wolfe BE, et al. Diet rapidly and reproducibly alters the human gut microbiome. Nature. 2014; 505:559-563. https://doi.org/10.1038/ nature12820 PMID: 24336217

21. Furusawa $Y$, Obata $Y$, Fukuda $S$, Endo TA, Nakato G, Takahashi $D$, et al. Commensal microbe-derived butyrate induces the differentiation of colonic regulatory T cells. Nature. 2013; 504:446-450. https://doi. org/10.1038/nature12721 PMID: 24226770

22. Zmora N, Zilberman-Schapira G, Suez J, Mor U, Dori-Bachash M, Bashiardes S, et al. Personalized Gut Mucosal Colonization Resistance to Empiric Probiotics Is Associated with Unique Host and Microbiome Features. Cell. 2018; 174(6):1388-1405.e21. https://doi.org/10.1016/j.cell.2018.08.041 PMID: 30193112

23. Proctor LM, Creasy HH, Fettweis JM, Lloyd-Price J, Mahurkar A, Zhou W, et al. The Integrative Human Microbiome Project. Nature. 2019; 569:641-648. https://doi.org/10.1038/s41586-019-1238-8 PMID: 31142853

24. Eisenhofer R, Minich JJ, Marotz C, Cooper A, Knight R, Weyrich LS. Contamination in Low Microbial Biomass Microbiome Studies: Issues and Recommendations. Trends Microbiol. 2019; 27(2):105-17. https://doi.org/10.1016/j.tim.2018.11.003 PMID: 30497919

25. Gottschick C, Deng ZL, Vital M, Masur C, Abels C, Pieper DH, et al. The urinary microbiota of men and women and its changes in women during bacterial vaginosis and antibiotic treatment. Microbiome. 2017; 55(1):99. https://doi.org/10.1186/s40168-017-0305-3 PMID: 28807017

26. Liu F, Ling Z, Xiao Y, Yang Q, Zheng L, Jiang P, et al. Characterization of the urinary microbiota of elderly women and the effects of type 2 diabetes and urinary tract infections on the microbiota. Oncotarget. 2017; 8(59):100678-90. https://doi.org/10.18632/oncotarget.21126 PMID: 29246012

27. Komesu YM, Richter HE, Carper B, Dinwiddie DL, Lukacz ES, Siddiqui NY, et al. The urinary microbiome in women with mixed urinary incontinence compared to similarly aged controls. Int Urogynecol J. 2018; 29(12):1785-95. https://doi.org/10.1007/s00192-018-3683-6 PMID: 29909556

28. Curtiss N, Balachandran A, Krska L, Peppiatt-Wildman C, Wildman S, Duckett J. Age, menopausal status and the bladder microbiome. Eur J Obstet Gynecol Reprod Biol. 2018; 228:126-9. https://doi.org/ 10.1016/j.ejogrb.2018.06.011 PMID: 29936400

29. Adebayo AS, Ackermann G, Bowyer RCE, Wells PM, Humphreys G, Knight R, et al. The urinary tract microbiome in older women exhibits host genetics and environmental influences. Cell Host Microbe [Internet]. 2020; 28(2):298-305.e3. Available from: http://www.sciencedirect.com/science/article/pii/ S1931312820303632 https://doi.org/10.1016/j.chom.2020.06.022 PMID: 32697939

30. Ammitzbøll N, Bau BPJ, Bundgaard-Nielsen C, Villadsen AB, Jense A-M, Leutscher PDC, et al. Preand postmenopausal women have different core urianry microbiota. Sci Rep. 2021; 11(2212).

31. Pederzoli F, Ferrarese R, Amato V, Locatelli I, Alchera E, Lucianò R, et al. Sex-specific Alterations in the Urinary and Tissue Microbiome in Therapy-naïve Urothelial Bladder Cancer Patients. Eur Urol Oncol. 2020; 3(6):784-8. https://doi.org/10.1016/j.euo.2020.04.002 PMID: 32345542

32. Lewis DA, Brown R, Williams J, White $P$, Jacobson SK, Marchesi JR, et al. The human urinary microbiome; bacterial DNA in voided urine of asymptomatic adults. Front Cell Infect Microbiol. 2013; 3(41).

33. Karstens L, Asquith M, Davin S, Stauffer P, Fair D, Gregory WT, et al. Does the Urinary Microbiome Play a Role in Urgency Urinary Incontinence and its Severity? Front Cell Infect Microbiol [Internet]. 2016; 6(78). Available from: https://www.frontiersin.org/article/10.3389/fcimb.2016.00078 PMID: 27512653

34. Brubaker L, Nager CW, Richter HE, Visco A, Nygaard I, Barber MD, et al. Urinary bacteria in adult women with urgency urinary incontinence. Obstet Gynecol Surv. 2014; 25(9):1179-84.

35. Thomas-White KJ, Hilt EE, Fok C, Pearce MM, Mueller ER, Kliethermes S, et al. Incontinence medication response relates to the female urinary microbiota. Int Urogynecol J. 2016; 27(5):723-33. https://doi. org/10.1007/s00192-015-2847-x PMID: 26423260

36. Liu F, Liu A, Lu X, Zhang Z, Xue Y, Xu J, et al. Dysbiosis signatures of the microbial profile in tissue from bladder cancer. Cancer Med. 2019; 8(16):6904-14. https://doi.org/10.1002/cam4.2419 PMID: 31568654 
37. Bučević Popović V, Šitum M, Chow CET, Chan LS, Roje B, Terzić J. The urinary microbiome associated with bladder cancer. Sci Rep. 2018; 8(12157). https://doi.org/10.1038/s41598-018-29054-w PMID: 30108246

38. Wu P, Zhang G, Zhao J, Chen J, Chen Y, Huang W, et al. Profiling the Urinary Microbiota in Male Patients With Bladder Cancer in China. Front Cell Infect Microbiol [Internet]. 2018 May 31; 8(167). Available from: https://www.frontiersin.org/article/10.3389/fcimb.2018.00167/full

39. Mansour B, Monyók Á, Makra N, Gajdács M, Vadnay I, Ligeti B, et al. Bladder cancer-related microbiota: examining differences in urine and tissue samples. Sci Rep [Internet]. 2020 Dec 6; 10:11042. Available from: http://www.nature.com/articles/s41598-020-67443-2 https://doi.org/10.1038/s41598020-67443-2 PMID: 32632181

40. Bi H, Tian Y, Song C, Li J, Liu T, Chen Z, et al. Urinary microbiota-a potential biomarker and therapeutic target for bladder cancer. J Med Microbiol [Internet]. 2019 Oct 1; 68(10):1471-8. Available from: https:// www.microbiologyresearch.org/content/journal/jmm/10.1099/jmm.0.001058 PMID: 31418671

41. Hourigan SK, Zhu W, Wong SWW, Clemency NC, Provenzano M, Vilboux T, et al. Studying the urine microbiome in superficial bladder cancer: Samples obtained by midstream voiding versus cystoscopy. BMC Urol. 2020; 20(5). https://doi.org/10.1186/s12894-020-0576-z PMID: 31992287

42. Chipollini J, Wright JR, Nwanosike H, Kepler CY, Batai K, Lee BR, et al. Characterization of urinary microbiome in patients with bladder cancer: Results from a single-institution, feasibility study. Urol Oncol Semin Orig Investig [Internet]. 2020 Jul; 38(7):615-21. Available from: https://linkinghub.elsevier. com/retrieve/pii/S1078143920301393

43. Siddiqui H, Lagesen K, Nederbragt AJ, Jeansson SL, Jakobsen KS. Alterations of microbiota in urine from women with interstitial cystitis. BMC Microbiol. 2012; 13(12):205. https://doi.org/10.1186/14712180-12-205 PMID: 22974186

44. Abernethy MG, Rosenfeld A, White JR, Mueller MG, Lewicky-Gaupp C, Kenton K. Urinary microbiome and cytokine levels in women with interstitial cystitis. Obstet Gynecol. 2017; 129(3):500-6. https://doi. org/10.1097/AOG.0000000000001892 PMID: 28178051

45. Bresler L, Price TK, Hilt EE, Joyce C, Fitzgerald CM, Wolfe AJ. Female lower urinary tract microbiota do not associate with IC/PBS symptoms: a case-controlled study. Int Urogynecol J. 2019; 30(11):1835-42. https://doi.org/10.1007/s00192-019-03942-9 PMID: 30993388

46. Meriwether K V., Lei Z, Singh R, Gaskins J, Hobson DTG, Jala V. The vaginal and urinary microbiomes in premenopausal women with interstitial cystitis/bladder pain syndrome as compared to unaffected controls: A pilot cross-sectional study. Front Cell Infect Microbiol. 2019; 8(9):92. https://doi.org/10.3389/ fcimb.2019.00092 PMID: 31024861

47. Nickel JC, Stephens-Shields AJ, Landis JR, Mullins C, van Bokhoven A, Lucia MS, et al. A Culture-Independent Analysis of the Microbiota of Female Interstitial Cystitis/Bladder Pain Syndrome Participants in the MAPP Research Network. J Clin Med. 2019; 8(3):415. https://doi.org/10.3390/jcm8030415 PMID: 30917614

48. Nickel JC, Stephens A, Landis JR, Mullins C, Van Bokhoven A, Lucia MS, et al. Assessment of the Lower Urinary Tract Microbiota during Symptom Flare in Women with Urologic Chronic Pelvic Pain Syndrome: A MAPP Network Study. J Urol. 2016; 195(2):356-62. https://doi.org/10.1016/j.juro.2015.09. 075 PMID: 26410734

49. Domingue GJ, Ghoniem GM, Bost KL, Fermin C, Human LG. Dormant Microbes in Interstitial Cystitis. J Urol. 1995; 153(4):1321-6. PMID: 7869536

50. Forster CS, Panchapakesan K, Stroud C, Banerjee P, Gordish-Dressman H, Hsieh MH. A cross-sectional analysis of the urine microbiome of children with neuropathic bladders. J Pediatr Urol. 2020; 16 (5):593.e1-593.e8. https://doi.org/10.1016/j.jpurol.2020.02.005 PMID: 32171668

51. Fouts DE, Pieper R, Szpakowski S, Pohl H, Knoblach S, Suh MJ, et al. Integrated next-generation sequencing of $16 \mathrm{~S}$ rDNA and metaproteomics differentiate the healthy urine microbiome from asymptomatic bacteriuria in neuropathic bladder associated with spinal cord injury. $\mathrm{J}$ Transl Med. 2012; 10 (174). https://doi.org/10.1186/1479-5876-10-174 PMID: 22929533

52. Pierre JF, Akbilgic O, Smallwood H, Cao X, Fitzpatrick EA, Pena S, et al. Discovery and predictive modeling of urine microbiome, metabolite and cytokine biomarkers in hospitalized patients with community acquired pneumonia. Sci Rep. 2020; 10(13418). https://doi.org/10.1038/s41598-020-70461-9 PMID: 32770049

53. Byron JK. Urinary Tract Infection. Vet Clin North Am—Small Anim Pract. 2019; 49(2):211-21. https:// doi.org/10.1016/j.cvsm.2018.11.005 PMID: 30591189

54. Ling $\mathrm{G} V$. Therapeutic strategies involving antimicrobial treatment of the canine urinary tract. J Am Vet Med Assoc. 1984; 185(10):1162-4. PMID: 6392247 
55. Knapp DW, Ramos-Vara JA, Moore GE, Dhawan D, Bonney PL, Young KE. Urinary bladder cancer in dogs, a naturally occurring model for cancer biology and drug development. ILAR J [Internet]. 2014 Apr 1; 55(1):100-18. Available from: https://doi.org/10.1093/ilar/ilu018 PMID: 24936033

56. Burton EN, Cohn LA, Reinero CN, Rindt H, Moore SG, Ericsson AC. Characterization of the urinary microbiome in healthy dogs. PLoS One. 2017; 12(5):e0177783. https://doi.org/10.1371/journal.pone. 0177783 PMID: 28545071

57. Melgarejo T, Oakley BB, Krumbeck JA, Tang S, Krantz A, Linde A. Assessment of bacterial and fungal populations in urine from clinically healthy dogs using next-generation sequencing. $J$ Vet Intern Med [Internet]. 2021 Mar 19;jvim.16104. Available from: https://onlinelibrary.wiley.com/doi/10.1111/jvim. 16104 PMID: 33739491

58. Siddiqui $\mathrm{H}$, Nederbragt $\mathrm{AJ}$, Jakobsen $\mathrm{KS}$. A solid-phase method for preparing human DNA from urine for diagnostic purposes. Clin Biochem. 2009; 42(10-11):1128-35. https://doi.org/10.1016/j. clinbiochem.2009.03.010 PMID: 19303866

59. Bergallo M, Costa C, Gribaudo G, Tarallo S, Baro S, Ponzi AN, et al. Evaluation of six methods for extraction and purification of viral DNA from urine and serum samples. New Microbiol. 2006; 29(2):1119. PMID: 16841551

60. El Bali L, Diman A, Bernard A, Roosens NHC, Dekeersmaecker SCJ. Comparative study of seven commercial kits for human DNA extraction from urine samples suitable for DNA biomarker-based public health studies. J Biomol Tech. 2014; 25(4):96-110. https://doi.org/10.7171/jbt.14-2504-002 PMID: 25365790

61. Karstens L, Siddiqui NY, Zaza T, Barstad A, Amundsen CL, Sysoeva TA. Benchmarking DNA isolation kits used in analyses of the urinary microbiome. Sci Rep [Internet]. 2021 Dec 17; 11(1):6186. Available from: http://www.nature.com/articles/s41598-021-85482-1 https://doi.org/10.1038/s41598-021-854821 PMID: 33731788

62. Ackerman AL, Anger JT, Khalique MU, Ackerman JE, Tang J, Kim J, et al. Optimization of DNA extraction from human urinary samples for mycobiome community profiling. PLoS One. 2019; 14(4): e0210306. https://doi.org/10.1371/journal.pone.0210306 PMID: 31022216

63. Buffone GJ, Demmler GJ, Schimbor CM, Greer J. Improved amplification of cytomegalovirus DNA from urine after purification of DNA with glass beads. Clin Chem. 1991; 37(11):1945-9. PMID: 1657454

64. Santiago-Rodriguez TM, Ly M, Bonilla N, Pride DT. The human urine virome in association with urinary tract infections. Front Microbiol. 2015; 6(14). https://doi.org/10.3389/fmicb.2015.00070 PMID: 25713565

65. Munch MM, Chambers LC, Manhart LE, Domogala D, Lopez A, Fredricks DN, et al. Optimizing bacterial DNA extraction in urine. PLoS One [Internet]. 2019; 14(9). Available from: https://doi.org/10.1371/ journal.pone.0222962 PMID: 31550285

66. Liu F, Ling Z, Xiao Y, Yang Q, Wang B, Zheng L, et al. Alterations of Urinary Microbiota in Type 2 Diabetes Mellitus with Hypertension and/or Hyperlipidemia. Front Physiol. 2017; 8(126).

67. Djukic M, Erler S, Leimbach A, Grossar D, Charrière JD, Gauthier L, et al. Comparative genomics and description of putative virulence factors of Melissococcus plutonius, the causative agent of European foulbrood disease in honey bees. Genes (Basel). 2018; 9(8):419. https://doi.org/10.3390/ genes9080419 PMID: 30127293

68. Adebayo AS, Survayanshi M, Bhute S, Agunloye AM, Isokpehi RD, Anumudu Cl, et al. The microbiome in urogenital schistosomiasis and induced bladder pathologies. PLoS Negl Trop Dis. 2017; 11(11)

69. Kramer H, Kuffel G, Thomas-White K, Wolfe AJ, Vellanki K, Leehey DJ, et al. Diversity of the midstream urine microbiome in adults with chronic kidney disease. Int Urol Nephrol [Internet]. 2018 Jun 12 [cited 2019 Sep 23]; 50(6):1123-30. Available from: http://www.ncbi.nlm.nih.gov/pubmed/29651696 https:// doi.org/10.1007/s11255-018-1860-7 PMID: 29651696

70. Nadkarni MA, Martin FE, Jacques NA, Hunter N. Determination of bacterial load by real-time PCR using a broad-range (universal) probe and primers set. Microbiology. 2002; 148(Pt 1):257-66. https://doi.org/ 10.1099/00221287-148-1-257 PMID: 11782518

71. Caporaso JG, Lauber CL, Walters WA, Berg-Lyons D, Huntley J, Fierer N, et al. Ultra-high-throughput microbial community analysis on the Illumina HiSeq and MiSeq platforms. ISME J. 2012; 6:1621-1624. https://doi.org/10.1038/ismej.2012.8 PMID: 22402401

72. Caporaso JG, Lauber CL, Walters WA, Berg-Lyons D, Lozupone CA, Turnbaugh PJ, et al. Global patterns of $16 \mathrm{~S}$ rRNA diversity at a depth of millions of sequences per sample. Proc Natl Acad Sci U S A. 2011; 18(Supplement 1):4516-22.

73. Boylen E, Ram Rideout J, Dillon MR, Bokulich NA, Abnet CC, Al-Ghalith GA, et al. Reproducible, interactive, scalable and extensible microbiome data science using QIIME 2. Nat Biotechnol. 2019; 37 (8):852-7. https://doi.org/10.1038/s41587-019-0209-9 PMID: 31341288 
74. Callahan BJ, McMurdie PJ, Rosen MJ, Han AW, Johnson AJA, Holmes SP. DADA2: High-resolution sample inference from Illumina amplicon data. Nat Methods. 2016; 13:581-583. https://doi.org/10. 1038/nmeth.3869 PMID: 27214047

75. Yilmaz P, Parfrey LW, Yarza P, Gerken J, Pruesse E, Quast C, et al. The SILVA and "all-species Living Tree Project (LTP)" taxonomic frameworks. Nucleic Acids Res. 2014; 42(Database Issue):D643-8. https://doi.org/10.1093/nar/gkt1209 PMID: 24293649

76. Quast C, Pruesse E, Yilmaz P, Gerken J, Schweer T, Yarza P, et al. The SILVA ribosomal RNA gene database project: Improved data processing and web-based tools. Nucleic Acids Res. 2013; 41(Database Issue):D590-596. https://doi.org/10.1093/nar/gks1219 PMID: 23193283

77. McMurdie PJ, Holmes S. Waste Not, Want Not: Why Rarefying Microbiome Data Is Inadmissible. PLoS Comput Biol. 2014; 10(4).

78. Davis NM, Proctor DM, Holmes SP, Relman DA, Callahan BJ. Simple statistical identification and removal of contaminant sequences in marker-gene and metagenomics data. Microbiome [Internet]. 2018 Dec 17; 6(1):226. Available from: https://microbiomejournal.biomedcentral.com/articles/10.1186/ s40168-018-0605-2 PMID: 30558668

79. McMurdie PJ, Holmes S. phyloseq: An R Package for Reproducible Interactive Analysis and Graphics of Microbiome Census Data. PLoS One. 2013; 8(4).

80. Martinez Arbizu P. pairwiseAdonis: Pairwise multilevel comparison using adonis. R package version 0.4. 2020.

81. Gloor GB, Macklaim JM, Pawlowsky-Glahn V, Egozcue JJ. Microbiome datasets are compositional: And this is not optional. Front Microbiol. 2017; 8(2224).

82. Hussing C, Kampmann ML, Mogensen HS, Børsting C, Morling N. Quantification of massively parallel sequencing libraries-A comparative study of eight methods. Sci Rep. 2018; 8(1110).

83. Charlebois RL, Sathiamoorthy S, Logvinoff C, Gisonni-Lex L, Mallet L, Ng SHS. Sensitivity and breadth of detection of high-throughput sequencing for adventitious virus detection. npj Vaccines. 2020; 5(61).

84. Fuhrman BJ, Feigelson HS, Flores R, Gail MH, Xu X, Ravel J, et al. Associations of the fecal microbiome with urinary estrogens and estrogen metabolites in postmenopausal women. J Clin Endocrinol Metab. 2014; 99(12):4632-40. https://doi.org/10.1210/jc.2014-2222 PMID: 25211668

85. Wirant SC, McGuire B. Urinary behavior of female domestic dogs (Canis familiaris): Influence of reproductive status, location, and age. Appl Anim Behav Sci. 2004; 85(3-4):335-48.

86. Nelson DE, van der Pol B, Dong Q, Revanna K V., Fan B, Easwaran S, et al. Characteristic male urine microbiomes associate with asymptomatic sexually transmitted infection. PLoS One. 2010; 5(11). https://doi.org/10.1371/journal.pone.0014116 PMID: 21124791

87. Siddiqui $\mathrm{H}$, Nederbragt $\mathrm{AJ}$, Lagesen $\mathrm{K}$, Jeansson $\mathrm{SL}$, Jakobsen $\mathrm{KS}$. Assessing diversity of the female urine microbiota by high throughput sequencing of $16 \mathrm{~S}$ rDNA amplicons. BMC Microbiol. 2011; 11 (244). https://doi.org/10.1186/1471-2180-11-244 PMID: 22047020

88. Oh C, Lee K, Cheong Y, Lee SW, Park SY, Song CS, et al. Comparison of the oral microbiomes of canines and their owners using next-generation sequencing. PLoS One. 2015; 10(7). https://doi.org/10 1371/journal.pone.0131468 PMID: 26134411

89. Honneffer JB, Steiner JM, Lidbury JA, Suchodolski JS. Variation of the microbiota and metabolome along the canine gastrointestinal tract. Metabolomics. 2017; 13(26).

90. Kerr KR, Forster G, Dowd SE, Ryan EP, Swanson KS. Effects of dietary cooked navy bean on the fecal microbiome of healthy companion dogs. PLoS One. 2013; 8(9). https://doi.org/10.1371/journal.pone. 0074998 PMID: 24040374

91. Dewhirst FE, Klein EA, Thompson EC, Blanton JM, Chen T, Milella L, et al. The canine oral microbiome. PLoS One. 2012; 7(6). https://doi.org/10.1371/journal.pone.0036067 PMID: 22558330

92. Ruparell A, Inui T, Staunton R, Wallis C, Deusch O, Holcombe LJ. The canine oral microbiome: Variation in bacterial populations across different niches. BMC Microbiol. 2020; 20(42). https://doi.org/10. 1186/s12866-020-1704-3 PMID: 32111160

93. Tress B, Dorn ES, Suchodolski JS, Nisar T, Ravindran P, Weber K, et al. Bacterial microbiome of the nose of healthy dogs and dogs with nasal disease. PLoS One. 2017; 12(5). https://doi.org/10.1371/ journal.pone.0176736 PMID: 28459886

94. Xenoulis PG, Palculict B, Allenspach K, Steiner JM, Van House AM, Suchodolski JS. Molecular-phylogenetic characterization of microbial communities imbalances in the small intestine of dogs with inflammatory bowel disease. FEMS Microbiol Ecol. 2008; 66(3):579-89. https://doi.org/10.1111/j.1574-6941. 2008.00556.x PMID: 18647355

95. Jacobs KM, Price TK, Thomas-White K, Halverson T, Davies A, Myers DL, et al. Cultivable Bacteria in Urine of Women With Interstitial Cystitis: (Not) What We Expected. Female Pelvic Med Reconstr Surg. 2020; 27(5):322-7. 
96. Komesu YM, Dinwiddie DL, Richter HE, Lukacz ES, Sung VW, Siddiqui NY, et al. Defining the relationship between vaginal and urinary microbiomes. Am J Obstet Gynecol. 2020; 222(2):154.e1-154.e10. https://doi.org/10.1016/j.ajog.2019.08.011 PMID: 31421123

97. Albertsen M, Karst SM, Ziegler AS, Kirkegaard RH, Nielsen PH. Back to Basics-The Influence of DNA Extraction and Primer Choice on Phylogenetic Analysis of Activated Sludge Communities. Aziz RK, editor. PLoS One [Internet]. 2015 Jul 16; 10(7):e0132783. Available from: https://dx.plos.org/10.1371/ journal.pone.0132783 PMID: 26182345

98. Thomas-White KJ, Kliethermes S, Rickey L, Lukacz ES, Richter HE, Moalli P, et al. Evaluation of the urinary microbiota of women with uncomplicated stress urinary incontinence. Am J Obstet Gynecol. 2017; 216(1):55.e1-55.16. https://doi.org/10.1016/j.ajog.2016.07.049 PMID: 27498309

99. Shrestha E, White JR, Yu SH, Kulac I, Ertunc O, De Marzo AM, et al. Profiling the Urinary Microbiome in Men with Positive versus Negative Biopsies for Prostate Cancer. J Urol. 2018; 199(1):161-71. https://doi.org/10.1016/j.juro.2017.08.001 PMID: 28797714 